\title{
Do return migrants transfer political norms to their origin country?
}

\section{Evidence from Mali ${ }^{1}$}

\author{
Lisa Chauvet $^{2}$ and Marion Mercier $^{3}$
}

This draft: December 2012

\section{Abstract}

This paper explores the link between return migration and political outcomes in the origin country, using the case study of Mali. We build a panel dataset combining the Malian censuses of 1998 and 2009 and electoral results at the locality level for the municipal elections of 1998/1999 and 2009. Using fixed effects estimations, we find a positive impact of the stock of returnees from non-African countries on participation rates, confirmed by various robustness checks, and we find evidence of a diffusion effect from those returnees to nonmigrants. We also put forward a substitution effect between the presence of returnees from both African and non-African countries and the level of education of the non-migrants: the transfer of electoral norms by returnees is stronger when non-migrants are poorly educated. Finally, we find a strong positive impact of migrants coming back from non-African countries on three indicators of electoral competitiveness.

\section{Keywords}

Return Migration. Elections. Mali. Norms transfer.

JEL codes: D72, F22, O15, O55

\footnotetext{
${ }^{1}$ We wish to thank the CEPREMAP for funding. We also thank Elodie Bonnefond, Danielle Delmas and Nelly Rakoto-Tiana for excellent research assistance.

We thank Catia Batista, Bastien Chabé-Ferret, Paul Collier, David de la Croix, Frédéric Docquier, Flore Gubert, Pierrick Judéaux, Fabio Mariani, Sandrine Mesplé-Somps, José de Sousa, Marie-Anne Valfort, Thierry Verdier, Ekaterina Zhuravskaya for very helpful comments.

We also thank the participants to the Development and Globalization seminar of the University of Paris 1, GLAMMS workshop, DIAL seminar, CSAE conference, EPCS congress, ADRES conference, EUDN PhD workshop and to the IRES seminar for useful discussions.

${ }^{2}$ DIAL, Institut de recherche pour le développement, Université Paris-Dauphine

${ }^{3}$ Paris School of Economics, EHESS, DIAL
} 


\section{Introduction}

This paper explores the link between return migration and political outcomes in the origin country, using the case study of Mali. Before the coup d'état of March 2012, Mali was referred to as one of the most successful stories of democratization in Africa since the beginning of the process in the nineties. Mali also has a long-lasting history of migration, both within West Africa and with the rest of the world. Malian migrants are actively involved in the economic development of their country. Besides sending remittances to their families at home, they also engage in hometown associations which contribute to financing public goods in their villages of origin. In this paper, we investigate the political implications of return migration.

Recently, new research has emerged on the political consequences of migration for the country of origin. Following Albert Hirschman's Voice - Exit - Loyalty terminology, Li and McHale (2006) define four channels through which emigration is likely to affect the quality of political institutions at home: (1) The 'absence' channel: skilled emigration removes from the country the most productive individuals, who are most likely to advocate for good governance (reduces 'voice') ; (2) The 'prospect' channel: the possibility to emigrate ('exit') offers to the most productive individuals more bargaining power (increases 'voice') ; (3) The 'diaspora' channel: emigrants can support political groups or social movements from abroad; (4) The 'return' channel: returnees come back with new ideas and are likely to promote specific political objectives (such as accountability, transparency, etc.).

Most studies use a cross-country approach to explore the impact of migration on the quality of political institutions. Li and McHale (2006) look at the impact of the stock of skilled emigrants in 1990 on the quality of the political and economic institutions of the origin country in 2000 and find that skilled emigration is associated with higher quality political 
institutions. Docquier et al. (2011) find a positive impact of unskilled migration on the polity score of developing countries. Beine and Sekkat (2011) also find that migration tends to improve political institutions of the sending country, with the notable exception of "voice and accountability" which is reduced by emigration, consistently with the voice/exit hypothesis. Their results are shown to hold for skilled migration and with a higher impact. Interestingly, the impact of migration on political institutions seems to depend upon the characteristics of the destination country, advocating for an interpretation of the results in terms of transfer of norms. In the same vein, Lodigiani and Salomone (2012) show that international migration to countries with higher female political empowerment significantly increases the parliamentary share of females in the origin countries. Similarly, Spilimbergo (2009) shows that foreigneducated individuals tend to promote democracy in their origin country if foreign education is acquired in democratic countries.

Micro-economic evidence on the political impact of migration for the origin country is even more recent. Batista and Vicente (2011) investigate the impact of migration on the demand for political accountability in the home country, relying on a "postcard voting experiment" in Cape Verde. They find that emigration in general, and the presence of returnees in particular, have a positive impact on the demand for political accountability and better governance. Again, the characteristics of the destination country seem to matter: the impact of migrants on the demand for political accountability in the origin country is higher when the destination country has better levels of governance. In a recent paper on Mexican municipal elections, Pfutze (2012) shows that migration significantly increases the probability that a party in opposition to the former state party wins a municipal election. Finally, Mahmoud et al. (2012) find that support for the Communist party in the parliamentary elections in Moldova is lower in localities with more migration to Western countries. 
In this paper, we explore the relationship between return migration and the participation to local elections in Mali. So far, no analysis has ever looked at the direct impact of return migrants on political outcomes, most studies focusing on emigration rates. Moreover, with the exception of Batista and Vicente (2011), Africa has never been the field of study for looking at the political consequences of migration. Finally, our study is the first to use a panel dataset at the level of the localities: we use the Malian censuses of 1998 and 2009 to explore the impact of return migration on participation rates at the local elections of $1998 / 1999^{4}$ and 2009. Our identification strategy relies on the fact that we can control for the time-invariant unobservable characteristics of localities that may be correlated with both participation rates and return migration intensity. Moreover, census data provide a lot of information regarding education, ethnic characteristics, and infrastructures that allow us to control for various potential determinants of participation. We implement various robustness tests and notably an IV procedure, instrumenting return migration using distance variables chosen to capture the easiness of access to migratory routes and to the main destination countries. Finally, we design specific tests to identify the existence of a diffusion effect from returnees to nonmigrants.

We find a positive impact of returnees from non-African countries on electoral participation, suggesting that return migration can affect the political involvement at home depending on the destination country of migrants. This impact is confirmed by the different robustness checks implemented. We also show that the impact of returnees from African countries, though it has a non-significant direct impact, turns out to be significant in the poorly educated localities. This suggests that the presence of return migrants substitutes for the education of the non-migrants. Finally we find a strong impact of returnees from non-

\footnotetext{
${ }^{4}$ The first local election was implemented in June 1998 in the 19 urban localities, in May 1999 in the rural areas of the regions of Kayes, Koulikoro, Sikasso and Ségou, and in June 1999 in the rural areas of the regions of Mopti, Tombouctou, Gao and Kidal.
} 
African countries on electoral behaviours: returnees coming back from non-African countries tend to enhance political competitiveness.

The following Section briefly presents the economic literature on the transfer of political norms by migrants and return migrants. Section 3 describes the Malian context. The econometric strategy and data used are presented in Section 4. We discuss the impact of return migration on participation in Section 5. In Section 6, we investigate the effect of return migration on alternative electoral outcomes. Finally, Section 7 summarizes the results and concludes.

\section{Returnees and the transfers of political norms to the origin country}

\section{Return migrants and the development of the origin country}

Most of the literature on return migration has focused on the occupational choice of migrants upon return and on the determinants of their entrepreneurial activities. Dustmann and Kirchkamp (2002) explore the determinants of the choice of activity of return migrants. Using a survey in which Turkish migrants in Germany were questioned before leaving Germany and after their return to Turkey, the authors show that out of those who are economically active when they return (around half of them), most chose entrepreneurial activity. They also find that better educated individuals are more likely to be active upon return, suggesting an accumulation of human capital during migration. However, using survey data on Tunisian return migrants, Mesnard (2004) finds little evidence of any human capital accumulation through temporary migration. She highlights another channel through which migration may influence the occupational choice when returning: savings accumulated abroad by temporary migrants allow them to overcome credit constraints for new business start-ups at return. Piracha and Vadean (2010) also find that return migrants in Albania are more likely to 
be entrepreneurs. Batista et al. (2010) put forward a similar result using data on Mozambique. Finally, Démurger and Xu (2011), using survey data on China, show that return migrants are more likely to be self-employed than non-migrants. Moreover, they find that some characteristics of the migration experience of returnees (in particular the number of job changes during migration and repatriated savings) matter in explaining the likelihood of being self-employed. Return migrants therefore seem to be a source of dynamism and job-creation for the home economy. Human capital accumulation and physical capital accumulation during migration - even temporary - allow migrants to start up new businesses when returning back home.

The migration experience has also been shown to impact other behaviors, notably fertility habits. According to the adaptation hypothesis, migrants' fertility rates tend to converge towards those of the natives of the destination country. For example, Lindstrom and Saucedo (2002) show that upon returning to Mexico, women with a migration experience in the U.S. tend to have slightly lower fertility rates. Interestingly, the convergence hypothesis has also been shown to work the other way around by Bertoli and Marchetta (2012) in the case of Egypt. They find that migrants returning from other Arab countries characterized by higher fertility rates than Egypt tend to have more children than non-migrants. Thus, return migrants, through different dimensions, seem to adopt abroad specific norms that are determined by their migration experience, and to stick to them after their return.

\section{Knowledge transfer}

One of the questions raised by the economic literature is whether the norms adopted by migrants during their experience abroad diffuse to their origin households and communities. The above cited study by Lindstrom and Saucedo on the fertility norms of Mexican migrants in the U.S. shows quite important diffusion effects to the origin community: "women living in 
communities with a 0.10 prevalence of female migration have $15 \%$ fewer children than women living in communities with a zero prevalence of female migration" (Lindstrom and Saucedo, 2002: 1361). The transfer of fertility norms has also been examined at the macro level. In a cross-country analysis for the year 2000, Beine et al. (2012) show that a one per cent decrease in the fertility norm ${ }^{5}$ reduces home country fertility by over $0.3 \%$.

The spillover effects of migration in terms of health knowledge are examined by Hildebrandt and McKenzie (2005). They measure health knowledge using the first principal component of a set of questions asking mothers whether they can name ten different contraceptive methods. They show that their indicator of health knowledge is positively correlated with the fact of being in a migrant household. They also find evidence of the diffusion to non-migrant households of health knowledge acquired during migration: an increase in the migration intensity of the locality increases the level of health knowledge of the non-migrant mothers.

Looking at a specific kind of health knowledge, Diabaté and Mesplé-Somps (2012) explore the impact of migration on excision practices in Mali. Combining a survey on excision conducted in 2009 with the 2009 census, the authors find that the percentage of return migrants per village is negatively correlated with the risk of excision at the individual level. They also find that people living in villages with a higher intensity of return migrants tend to be better informed about the negative consequences of excision for women's health.

\section{Transfer of political norms}

The adoption by migrants of knowledge and new ideas during their migration experience is also likely to matter for their voting behaviour. Fidrmuc and Doyle (2006) analyse the voting behaviour of Czech and Polish migrants. They show that those who settled in Western

\footnotetext{
${ }^{5}$ Fertility norm is measured as the average fertility rate in the destination countries, weighted by the proportion of emigrants living in each destination country.
} 
Europe, North America and Australia tend to vote differently from the non-migrant population, which is not the case of migrants living in former communist countries. The political preferences of migrants thus appear to be affected by the characteristics of the host countries.

New political norms may spill over to the origin households of migrants and to their communities. Migrants keep narrow links with their family back home. In a recent work, Dedieu et al. (2012) conducted a survey of Senegalese migrants voting in France and in the U.S. to the presidential and legislative Senegalese elections in 2012. They show that the connections between migrants and their family manifest themselves through the sending of remittances, but also through regular phone contacts: out of 500 Senegalese migrants surveyed, $19 \%$ declared that they had phone contacts with their family on a daily basis, and $50 \%$ on a weekly basis. Migrants are also found to be strongly involved in hometown associations (HTAs) which contribute to financing public goods such as schools and health facilities in their village of origin. In the case of Senegalese migrants, around $30 \%$ of the interviewees declared being members of a migrant association. The connections between migrants and their family in the origin country also induce the transfer of political ideas and norms. Many respondents to the survey declare trying to influence the political practices of their family: $66 \%$ encouraged members of their family back home to register on the electoral lists and over $40 \%$ gave voting guidance.

The transfer of political norms has first been tested at the macro level (Li and McHale, 2006; Spilimbergo, 2009; Docquier et al., 2011; Beine and Sekkat, 2011; Lodigiani and Salomone, 2012). These studies suggest that there is an impact of migration on the quality of political institutions in the origin country. This impact seems to be determined by some political characteristics of the host countries, as well as by the characteristics of the migrants notably in terms of education. 
Another approach to the political transfer of norms by migrants uses micro data and focuses on how political opinions and behaviours at home change with migration. In this literature, there is a trade-off between using electoral outcomes (rather than self-reported declarations on political attitudes or opinions) and measuring accurately the diffusion of political norms. Using data on electoral outcomes implies working at the locality level, which precludes looking directly at how non-migrants individuals are influenced by the intensity of migration or return migration. Individual data therefore allow a precise estimation of the diffusion of political norms, that locality-level analysis do not. This accuracy comes at the cost of indirect measures of political behaviour.

Batista and Vicente (2011) conducted an experimental study in Cape Verde, which rebuilds the conditions of a referendum about political accountability to capture the demand for better governance at the individual level. While conducting a household survey focusing on perceived corruption in the public sector, they offered respondents the possibility to anonymously send back a postcard asking for the disclosure of the survey's results by the media. They show that the proportion of international migrants in the locality of the individuals has a positive impact on the probability to send back this postcard. PerezAmendariz and Crow (2009) also examine the impact of migration on individual political attitudes and participation (like satisfaction with democracy, non-electoral activity, protest), relying on survey data in Mexico. They report that migration experience impacts political attitudes and participation, and that this effect diffuses to the family back home, thus making a strong case that migrants are agents of democratic diffusion. These two individual-level studies describe an important impact of migration experience on the political opinions of migrants themselves but also on those of their non-migrant relatives. In both articles, the diffusion of political norms is directly tested as the impact of the locality-level migration intensity on individual political behaviours. 
Pfutze (2012) and Mahmoud et al. (2012) both investigate the impact of migration on electoral outcomes at the locality level, respectively focusing on the probability that a party in opposition to the former state party in Mexico wins a municipal election, and on the share of votes for the Communist party in the parliamentary elections in Moldova. Their results are very consistent with each other since they both find a positive impact of migration intensity on the electoral success of opposition parties. This approach allows testing the impact of migration on observed electoral data rather than self-reported declarations on political attitudes. However, the evidence for the diffusion of transfer of political norms is weaker. As noted by Mahmoud et al. (2012) the effect of migration on electoral results "can be attributed to changes in voting behaviour of migrants themselves, while there are no spillover effects on other community members". In order to disentangle the precise contribution of migration intensity on non-migrants' individual behaviours, Mahmoud et al. (2012) complement their locality-level analysis with an individual-level exit poll. They show that the probability that a non-migrant vote for the Communist party is negatively correlated with the prevalence of westward migration in the locality, thus putting forward a spillover effect.

In this paper, we examine the impact of the share of return migrants on electoral outcomes. We find a positive impact of returnees from non-African countries on participation to local elections. This positive correlation could derive from the fact that returnees have acquired political norms from their migration experience, without involving any diffusion effect whatsoever. To test for the existence of a diffusion effect, we identify 41 localities in our sample that had no returnees both in 1998 and in 2009, and show that their participation rates are positively correlated with the share of returnees from non-African countries of their neighbouring localities. We also simulate the gain, in terms of participation, that would be associated with having all the returnees voting, and compare it to the gain associated with the 
presence of returnees that is predicted by our empirical model. Finally, we document a substitution effect between return migration and the level of education of the non-migrants.

Different methodologies have been implemented in the literature to try to properly identify the effect of migration and in particular to control for the potential unobserved heterogeneity and omitted variables. Mahmoud et al. (2012) rely on the fact that Moldovan waves of migration started relatively recently, and thus they control for the pre-migration political preferences of the localities. Pfutze (2012) also introduces a proxy for the political preferences of the localities, using the federal electoral results as a control. Moreover, he takes into account whether an opposition government ever won an election since 1980 to identify the competitive localities. He shows that the impact of migration on the probability of a political switch is concentrated on less competitive municipalities, while the localities which are ex-ante more competitive are not affected by migration. Additionally, Pfutze (2012) implements an instrumental variable procedure, relying on historical migration data and on the distance to Juarez, the main point of entry to the U.S. in the early period of Mexican migration. Batista and Vicente (2012) also check the robustness of their findings with an instrumentation strategy. Similarly to Pfutze (2012), they use past migration as an instrument. They also use some macro indicators related to the host countries. Moreover, they aggregate their migration variables at the locality level in order to mitigate self-selection concerns regarding the unobservable characteristics of migrants and returnees. In our paper, the panel dimension of the data allows us to control for time-invariant heterogeneity across the Malian localities. Moreover, census data offers many control variables, which limits the risk of omitted variable bias and allows us to control for locality-level characteristics that may be correlated with migration (average education, wealth). To verify that our results are not biased by endogeneity, in particular if return migrants decide where to settle down in function of the political characteristics of the localities, we study the impact of returnees who came back in 
the district where they were born. We also implement an IV procedure as a further robustness check, relying on distance variables as proxies for the access to the migration routes.

Lastly, the micro-oriented literature on the transfer of political norms by migrants suggests that the impact of migration on political outcomes depends on the characteristics of the destination country. In particular, Batista and Vicente (2011) find evidence that migration intensity affects positively the individual demand for accountability when migrants settled in the United States, while the proportion of migrants to Portugal does not have a clear impact. Similarly, Mahmoud et al. (2012) report that the percentage of migrants increases the share of votes for the Communist party when migrants moved to countries with a relatively low quality of political institutions, while it decreases the share of votes for the Communist party when migrants moved to countries with a high quality of political institutions. In this study, we also explore the respective impact of returnees coming back from different destinations, distinguishing between African and non-African countries. Despite the fact that this distinction is relatively crude, we do find a differential impact of return migration according to these two destinations.

\section{The Malian political context}

Until March 2012, Mali was considered as having some of the most performing political institutions in Africa. Annex A presents the evolution from 1960 of the index of democracy provided by the Polity IV database, against the average levels observed in Africa and West Africa. The Malian democratization started in 1991, 31 years after the independence, with the coup of Amadou Toumani Touré against the authoritarian regime of Moussa Traoré. Between 1991 and 1992, Touré led the Comité Transitoire pour le Salut du Peuple, dedicated to lead the country through democratization. The election of 1992, wined by Alpha Oumar Konaré, was the milestone of this political process making of Mali one of the few examples of African 
democratization successes. From 1992 and during twenty years, the country managed to maintain democracy, in spite of the troubles affecting the 1997 presidential and legislative elections. Those incidents, which led to a boycott by a part of the opposition, ${ }^{6}$ finally did not jeopardize the tenure of the elections but undoubtedly helped the re-election of the incumbent, A. O. Konaré. After two mandates, his party, ADEMA, chose Soumaïla Cissé as a candidate for the 2002 presidential elections. But he was defeated by the non-partisan, though close to ADEMA candidate, Amadou Toumani Touré. Touré, supported by a large coalition of parties (including ADEMA) was then re-elected in 2007, for a second mandate. He remained the leader of the executive power in Mali until being overthrown by the military coup of March $22^{\text {nd }}, 2012$, one month before the presidential election to which he was not a candidate.

Despite a soft transition to democracy, the Malian system had already proven to be fragile before the coup of March 2012. Since 1991, participation to elections has remained low and the population has stayed poorly involved in the political life. In 2001, the Malian population exhibited the lowest level of political interest of all the countries surveyed by the Afrobarometer. Bratton et al. (2002) underline that even if a great majority of Malians supports democracy, $30 \%$ of them do not know the meaning of the word 'democracy'.

Electoral participation increased on average between the end of the nineties and 2009, both in the local and legislative elections, but remained relatively low. Table 1 and Figure 1 show the participation rates by localities (communes) in 1999 and 2009. Legislative elections are characterized by a lower participation than local elections: in the local ballot of 1999 , turnout was around $36 \%$, and it nearly reached $42 \%$ in 2009 , while in legislative elections, it was lower than $23 \%$ in 2002 and reached $30 \%$ in 2007 . Thus, the low, though slightly increasing, popular interest for political life appears to be the first weakness of the Malian political system before 2012. Moreover, before the coup of 2012, Sandbrook (1996) described

\footnotetext{
${ }^{6}$ The boycott was due to the very bad organization of the ballot, and defaults in the setting of the electoral lists.
} 
the Malian party system as highly fragmented, with political parties based on personal, ethnic or regional cleavages rather than ideological considerations, characterized by clientelist relationships with the voters, and finally depending on unstable governing coalitions. All those aspects are emphasized by most of the authors who studied the Malian political life. In particular, Bratton et al. (2002) underline the clientelist legacy that affected the relationships between voters and political leaders and which represented a major threat to the legitimacy of the Malian state.

[ Table 1 around here]

Political leaders have tried to address these weaknesses of the political system. In particular, they implemented an ambitious decentralization program, designed to bridge the gap between the population and the political arena, and to tackle the legacy of centralized and clientelist governance. The decentralization program was launched with the creation of the communes in 1996, after four years of debate. ${ }^{7}$ In 1999 , the Malian villages have finally been regrouped into 703 communes, 49 cercles and nine regions, which obtained the status of decentralized constituencies with elected leaders. Since then, all the administrative levels of the Malian territory have been managed by population-elected leaders.

In spite of those efforts, the political system existing in Mali before March 2012 was undoubtedly suffering a tendency of fragmentation, clientelism and instability within the political parties. The number of parties has exploded since 1991, reaching 120 in 2009! Most of these parties are locally-based, and do not have the capacity to become credible national parties. Within the multitude of existing parties, less than 30 have been represented at the Assembly since 1992. The political life has been dominated, since 1991, by the Alliance pour

\footnotetext{
${ }^{7}$ The MDD - Mission de Décentralisation et de Déconcentration - was created in 1992. The new territorial subdivisions have been designed in a participative and non-bureaucratic way, so as to take into account demands of each locality.
} 
la Démocratie au Mali (ADEMA) party, both at the national and at the local level. A few other political formations are stable national parties and have regularly been represented in national and local elections since $1992 .^{8}$ ADEMA became the dominant party of Mali after having fought Traoré's dictatorship. It obtained a large majority at the assembly during the legislative elections of 1992. Its candidate Alpha Oumar Konaré won the presidential election the same year. Even if a lot of divisions and merges occurred between different factions of ADEMA in the nineties, it remained the dominant party both at the legislative and local elections. As illustrated by Table 1, this pattern was moderated in 2002 when Amadou T. Touré, competing under an independent candidature, was elected President. In the second round, Touré wined $65 \%$ of the votes against the ADEMA candidate. Even if this could prima facie be interpreted as a popular signal against the domination of ADEMA, Touré was not an anti-ADEMA candidate, and he was supported by some eminent members of ADEMA. ADEMA remained a strong party, and the first political force in Mali, with a solid local support as the results of the 2004 and 2009 local elections attest. However its domination at the local level declined between 1999 and 2009, as it appears in Figure 1 which shows the share of votes for ADEMA by communes in 1999 and 2009. In particular, the communes of the regions of Kayes and Koulikoro, and, to a lesser extent, of Ségou and Mopti, that were largely dominated by ADEMA in 1999, exhibited large decreases in the share of votes obtained by the party in 2009 .

[Figure 1 around here]

Thus before the coup of March 2012 that disrupted the Malian political institutions, the situation in Mali was quite specific, combining a soft democratization, but with low

\footnotetext{
${ }^{8}$ Like the RPM (Rassemblement pour le Mali), the URD (Union pour la République et la Démocratie), the CNID (Congrès national d'initiative démocratique), the US-RDA (Union Soudanaise - Rassemblement Démocratique Africain), the MPR (Mouvement Patriotique pour le Renouveau) and the BDIA (Bloc pour la démocratie et l'intégration africaine)
} 
participation rates; and a vivid party-system, but with a major party dominating a highly fragmented set of parties. Moreover, the democratization was strongly weakened by legacies of clientelism, latent corruption, and a climate of inertia with respect to the security threats in the Northern regions. These are probably some of the elements at the roots of the coup d'état that overthrew A. T. Touré from power.

\section{Model and data}

We investigate the impact of return migration on various political outcomes measured for the two local elections of $1998-1999^{9}$ and 2009 , at the level of the localities. The general specification is the following:

$$
\text { PoliticalOutcome }_{c, t}=\alpha+\beta X_{c, t}+\text { SReturnMigration }_{c, t}+\mu_{c}+\tau_{t}+\varepsilon_{c, t}
$$

where PoliticalOutcome $_{c, t}$ is either the participation rate or alternative electoral outcomes in commune $c$ for the election held at time $t . X_{c, t}$ is a vector of socio-economic and demographic control variables for commune $c$ at time $t$. We also include the number of lists competing in the considered ballot to control for the competitiveness of the election. ReturnMigration ${ }_{c, t}$ is the variable of interest, the share of return migrants in the population of commune $c$, measured at time $t$. The error term, $\varepsilon_{c, t}$, is clustered within communes so as to account for the potential correlation of error terms within communes. The panel dimension of the database allows us to include communes fixed effects, $\mu_{c}$. Thus, we are able to control for the time-invariant unobservable characteristics of the communes that affect electoral outcomes. We also add a time dummy, $\tau_{t}$. In the rest of the paper, we refer to the communes as localities.

\footnotetext{
${ }^{9}$ The first local election was implemented in June 1998 in the 19 urban localities, in May 1999 in the rural areas of the regions of Kayes, Koulikoro, Sikasso and Ségou, and in June 1999 in the rural areas of the regions of Mopti, Tombouctou, Gao and Kidal.
} 
Our vector of control variables $X_{c, t}$ is a set of variables likely to influence political outcomes. Two kinds of variables have been identified in the literature as explaining participation: institutional variables - which are not relevant in our case, since political institutions do not vary from 1998 to 2009 , nor from one locality to another -, and socioeconomic and demographic variables. In a pioneer study, Powell (1982) shows that country size and economic development are key determinants of participation. First, he shows that the participation rate is higher in very small countries, maybe because voters feel more concerned about politics and more influent on the outcome of elections. Oliver (2000) confirmed this result by finding the same pattern at the local level: smaller constituencies tend to have a higher participation rate. Second, Powell suggests that richer countries tend to vote more. At the macro level, this result has then been moderated, and it seems that the relationship between aggregate income and participation is more complex, with a likely non-linear relationship (Blais and Dobrzynska, 1998). At the individual level, a few variables are rather consensually influent: namely gender, age and education. But the direction of their impact is not certain. For Ashenfelter and Kelley (1975), men, older and more educated people vote more. If their conception of a linear positive link between education and the propensity to vote has become consensual, the effect of age is less clear. Indeed, some authors suggest a non-linear relationship, the youngest and the oldest participating less than the medium-aged citizens (for instance, Highton 2000).

In line with the literature on voting behaviour, our estimations take into account the size of the locality, proxies for wealth and education. Gender and age are not relevant since neither the average age nor the percentage of male vary much from one locality to the other. Finally, ethnicity is often underlined as determining votes, notably in African countries. As shown by Bossuroy (2007) in the case of Ghana, ethnic cleavages are an important determinant of votes, though not the ruling one. In the case of Mali, Dunning and Harrison (2010) show through an 
experimental study that the traditional "cousinage" linkages in Mali tend to counterbalance ethnic cleavages, thus weakening ethnic voting. Yet, we include the percentage of the population from each of the main ethnic group, taking the majority group (the Bambara) as the reference.

All the right-hand side variables are computed within the population aged over eighteen, so as to be sure that we control for the composition of the voting-age population of the locality. These variables come from the "Recensement Général de la Population" (INSTAT, 1998 and 2009), two exhaustive censuses realized in 1998 and 2009. They provide data at the individual, household and village levels, that we aggregate at the locality level ${ }^{10}$. Electoral results, as well as the number of lists competing, are available at the locality level, from the Institut National de la Statistique Malien. The following describes the control variables included in the estimations:

- POPULATION: Logarithm of the population of eighteen years old and more living in the locality (RGPH, 1998 and 2009).

- LITERACY: Literacy rate within the population aged eighteen and more (RGPH, 1998 and 2009).

- WEALTH: Composite index of wealth per capita calculated using data on habitation and computed at the level of the localities. It takes into account the types of walls, of roof, of ground and of toilets in households' habitations (RGPH, 1998 and 2009).

- PEUHL, DOGON, MAURE, SONRAF, SONINKE, MINIANKA, TAMACHEQ, OTHER: Share of the population of the locality aged eighteen and more from a given ethnic group, based on spoken language (RGPH, 1998 and 2009). We

\footnotetext{
${ }^{10}$ On average, each locality gathers 15 villages.
} 
include the eight main ethnic groups of Mali (around 70\% of total population), taking the Bambara (more than $40 \%$ of total population) as the reference.

- LISTS: Number of lists competing in the considered ballot for the considered constituency.

- RAIN SHOCKS: standard deviation of the rain shocks suffered by the locality. Data on rainfalls come from the Climatic Research Unit, University of East Anglia. First we regress the level of yearly observed rainfalls on their lagged values and a time trend. From these estimations we predict the residuals and calculate their standard deviation over the ten years preceding the two ballots (period 1988-1998 and 1999-2009, respectively). This variable aims at controlling for the variability of the climatic conditions, that is likely to affect people's propensity to go to the polls.

- When we do not include localities fixed effects, PARTICIPATION to the previous ballot is added as a control variable.

\section{Data on electoral outcomes}

We use data on electoral outcomes in Mali (INSTAT) at the locality level for the two local ballots $^{11}$ of 1998/1999 and 2009. Local elections are one round proportional elections. Our central dependant variable is the participation rate which reflects the well-functioning of a democracy. Participation to election can also be interpreted as an indicator of people's dissatisfaction with their political leaders. Still, we believe that participation gives a good idea of the vivacity of the democratic activities. In a second step, we explore the impact of migration on alternative electoral outcomes that reflect the competitiveness of the elections of 1999 and 2009. We use three variables which measure respectively: (1) the size of the

\footnotetext{
${ }^{11}$ Local ballots are those where the Mayor and the municipal council are elected.
} 
majority (MAJ, the share of votes obtained by the winner); (2) the dispersion of the votes (FRAG, index of fragmentation, equalling one minus the Herfindahl index based on the share of votes obtained by each party); (3) the gap between the winner and the challenger (GAP, the difference between the shares of votes obtained by first and second lists).

\section{Data on migration}

Mali exhibits a strong dynamics of migration, both internal and external. It is a country of net emigration, but emigration flows have diminished in volume after the nineties. Table 2 shows that the number of Malian living abroad was estimated around 3.7 million in 1995 ( $27 \%$ of total population) and 2.7 million in 2001 (20\% of total population). Rural areas are the main supplier of emigrants: in 1996, the CERPOD (Centre d'études et de recherches sur la population et le développement) estimated that $73 \%$ of emigrants were coming from rural areas. Around $40 \%$ of emigrants are motivated by labour-oriented reasons, and a majority of them are men (CERPOD, 1996).

Most of the Malians who migrate move to another African country, and most often in Western Africa, as shown in Table 2. At the end of the nineties, Côte d'Ivoire was the main destination of emigration (more than $30 \%$ of the Malian migrants), followed by Burkina Faso (about 28\%) (Recensement des Maliens de l'Extérieur, 2001). The region of Kayes is particularly known to send migrants to Europe. On the contrary, international migration from the North of the country is mostly directed towards Ghana, Niger and Nigeria.

[Table 2 around here]

In this paper, we focus on the impact of return migration, measured as a share of the population aged over eighteen in 1998 and 2009, on Malian voting behaviour. The information regarding return migration comes from the "Recensement Général de la 
Population" (RGPH, 1998 and 2009). One question of the census is: "Did X reside elsewhere during more than six months?". If the answer is yes, the respondent is asked "Where was $X$ residing immediately before coming where he currently is?". We can thus identify return migrants knowing in which continent they migrated, and being sure that their episode of migration lasted more than six months.

The RGPH data report 287,497 Malian return migrants from foreign countries in 1998 (about $3 \%$ of population), $95 \%$ of them coming back from African countries. In 2009, the stock of returnees reaches 436,385 (still $3 \%$ of the population), $87 \%$ of them coming back from Africa. Return migration has thus experienced an increasing trend between 1998 and 2009, and especially return from non-African countries. As shown by Ndione and Lombard (2004) return is often an important step in the process of migration, and it classically takes part of the initial project of migration. But even if most of the returns are spontaneous, the phenomenon is not independent from historical contingency: the observed increasing tendency is thus probably partly explained by the political and economic crises suffered by most of the Western African countries and by the simultaneous development of growing xenophobia. ${ }^{12}$ Strong "push" factors from the receiving countries also exist in the non-African host countries (especially Europe) where the conditions of living for immigrants have become harsher.

Figure 2 shows how return migration in Mali varies both in space and in time. The three left-hand maps respectively report the shares of returnees, of returnees from Africa and of returnees from non-African countries in the population in 1998. The three same maps are shown on the right-hand side for 2009. In 1998 as in 2009, the Southern region of Sikasso, the Western region of Kayes and the Northern regions of Tombouctou, Gao and Kidal are the main returning areas for migrants coming back from African countries. Return migration to

\footnotetext{
${ }^{12}$ In particular, the political crisis in Côte d'Ivoire which started at the beginning of the 2000s had important repercussions for Malian people living in Côte d'Ivoire, many of them being forced to return to Mali.
} 
the region of Kayes is very specific. Though it becomes less obvious in 2009, a large part of return migration from non-African countries is targeted to Kayes. The fact that the region of Kayes is the main provider of migrants and return migrants from non-African countries (mainly from France) ${ }^{13}$ is due to historic reasons dating back to the colonial era and particular relationships built between the French colonizers and the Soninké ethnic group, mainly represented around Kayes. Annex B provides descriptive statistics of the demographic, socioeconomic and education characteristics of Malian returnees, by previous host country.

[Figure 2 around here]

5. The impact of return migration on participation

\subsection{Benchmark estimation}

We first explore whether returnees influence the participation rates in the localities where they live. We rely on the spatial and temporal variability of turnout (observed in 1998/1999 and 2009) and of the stock of returnees, measured as the share of returnees in the population aged over eighteen of each locality in 1998 and 2009. We estimate the impact of the stock of returnees, and then disaggregate this stock between the returnees coming back from African countries and the returnees coming back from the rest of the world. As shown in Table 3, returnees from Africa mainly come back from Côte d'Ivoire (59\% of the returnees from Africa in 1998, 61.5\% in 2009). Other neighbouring countries like Burkina Faso or Senegal are also a source of return migration to Mali, but in a much smaller proportion. Out-of-Africa destination countries of Malian returnees have greatly diversified between 1998 and 2009. Return migrants from non-African countries are still coming back predominantly from

\footnotetext{
${ }^{13}$ In the Kayes region, $93 \%$ of return migrants from non-African countries come back from France.
} 
Europe, but the share of returnees from France, among out-of-Africa returnees, fell from $65 \%$ to $24 \%$. New destinations in Europe, such as Spain, have developed. China is becoming more important since the share of return migrants from China has increased from less than $1 \%$ in 1998 to more than 5\% in 2009. New destinations have also appeared in Asia and in America.

[Table 3 around here]

Table 4 presents the benchmark results in pooled OLS and fixed-effects estimations. Columns (1) and (2) estimate the impact of RETURNEES, while columns (3) and (4) distinguish between returnees from African and non-African countries. When implementing pooled OLS estimations, we observe, as expected, a strong hysteresis in PARTICIPATION. However, the number of lists does not appear to be determinant regarding participation. Concerning the socio-demographic variables, POPULATION has a negative impact on turnout, consistently with the literature. LITERACY positively affects turnout, but is only slightly significant. More surprisingly, WEALTH exhibits a negative correlation with participation rates. Certain ethnic groups tend to vote more than the Bambara (the reference group), notably the SONRAI and the MINIANKA. Finally, RAIN SHOCKS are found to negatively affect participation in pooled OLS.

The pooled OLS provide a slightly significant and positive coefficient for the RETURNEES variable. When disaggregating by destination, we find a non-significant effect of RETURNEES - AFRICA, while the coefficient for RETURNEES - REST OF THE WORLD is positive and significant. This suggests that localities with a larger stock of returnees from non-African countries tend to exhibit higher levels of turnout in the local elections. However this result could be driven by many unobservable characteristics of the localities. 
[Table 4 around here]

We thus implement fixed-effects estimations, which allow controlling for all the timeinvariant unobservable characteristics of the localities, in columns (2) and (4). The results of the fixed-effect estimations are very close to those in pooled OLS. The impact of RETURNEES turns out to be insignificant, and RETURNEES - AFRICA remains insignificant. RETURNEES - REST OF THE WORLD keeps a significant and positive correlation with turnout. Thus, when controlling for the time-invariant characteristics of the localities, which are likely to affect both participation and the stock of returnees, neither the global stock of returnees nor the stock of returnees from Africa appear to have a direct impact on participation. However, the stock of returnees coming back from non-African countries exhibits a strong positive coefficient. Quantitatively speaking, the estimated coefficient for RETURNEES - REST OF THE WORLD suggests that a one percentage point increase in the share of returnees from non-African countries within the population aged over eighteen is associated with a 0.8 percentage point increase in the participation rate.

\subsection{Robustness checks}

The baseline estimations suggest that Malian returnees from non-African countries have a positive and significant impact on participation rates while Malian returnees from African countries do not. To strengthen the confidence in this result, we implement various robustness checks presented in Tables 5 to $8 .^{14}$

\footnotetext{
${ }^{14}$ We also looked at whether the results are driven by outlier observations. We followed Welsch and Kuh (1977) and Belsley, Kuh and Welsch (1980), to detect the potential outliers. The estimated coefficients for the three variables of return migration are similar to the benchmark results when outliers are excluded from the sample (results available upon request).
} 
First, the results presented above may be biased by endogeneity issues. At the individual level, those who leave and come back may have certain unobservable characteristics that are correlated with their propensity to vote and to migrate (for instance, their level of risk aversion). This generates an endogeneity bias. Such a selection issue may be mitigated by the fact that our data are at the locality level (see also Batista and Vicente, 2011). Moreover, the introduction of locality fixed-effects controls for all the time-invariant unobservable characteristics of the locality, which may also reduce the endogeneity issue. However, it misses to take into account the time-variant unobservable characteristics that potentially affect participation and return migration. For instance, one could suspect that return migrants choose the locality where they settle down depending on political characteristics (like the type of local leadership), correlated with participation. We rely on two different methodologies to take into account this potential endogeneity bias: (1) we build an alternative measure of the stock of returnees, selecting only returnees who returned in the district where they were born, and who most likely did not choose their locality of residence according to political considerations; (2) we implement an instrumental variable procedure.

Second, the statistical correlation between the share of returnees from non-African countries and the participation rate is not a direct test for the transfer of norms from returnees to non-migrants of the same locality. It may be the case that returnees have a higher propensity to vote, which would induce a positive correlation between their share in the locality and the participation rate, without implying any diffusion to non-migrants. As a preliminary check, we verify that return migrants from a foreign country have a different impact on participation rates than return migrants from other regions of Mali. We then test the potential diffusion effect by: (1) examining if the participation rate of localities with no return migrants from non-African countries is influenced by the share of return migrants from nonAfrican countries in the neighbouring localities; (2) simulating the gain in terms of 
participation associated with the assumption that all the returnees vote, and compare it to the gain associated with the presence of returnees predicted by our empirical model.

Third, we examine the mechanism through which the transfer of political norms by return migrants to their locality of origin may occur. If the positive correlation between returnees and participation is explained by a transfer of norm, this transfer may depend on the characteristics of the non-migrants. Moreover, if the impact of returnees depends on the characteristics of the non-migrants, then the interpretation in terms of transfer of norms is the most plausible. We look at whether the specific knowledge acquired abroad may substitute for education of the non-migrants. To do so, we introduce the interaction between the share of returnees and the share of educated non-migrants in the locality. We test four alternative measures of education for the non-migrants: literacy rate, primary, secondary and tertiary education.

\section{Addressing the endogeneity bias}

Table 5 presents the two first tests, designed to tackle the endogeneity issue. First, columns (1) and (2) reproduce the benchmark estimations, restricting the share of returnees to those who settled in the locality where they were born after having migrated abroad, and thus who probably did not choose their locality of residence according to political considerations. The estimated results are very close to the benchmark table, with an even stronger impact of returnees from non-African countries. This suggests that returnees from non-African countries have a positive impact on participation rate that is all the more important as returnees settle down in the locality where they were born. This result is very consistent with the interpretation in terms of transfer of political norm, since returnees who come back in the locality where they were born may have a larger network around them, and thus a larger number of relatives with whom sharing their newly acquired electoral norms. 
Columns (3) and (4) then present the second-step of the instrumental variable estimations. Finding satisfactory instruments for the intensity of return migration is difficult, and remains debated in the literature. A common strategy for instrumenting stocks of migrants relies in the use of distances, which are generally good predictors of the migration intensity. We instrument the stock of returnees with distance variables in order to capture the access to the migratory routes and destination countries. Since we implement fixed-effect estimations, we interact the distances with a period variable, so as to generate temporal variability in the instruments. More precisely, we use two variables to capture the migratory routes: the distance to Bamako, on the one hand, and the distance to the traditional migratory route on the other. Historically, Malian migration mainly emanated from the region of Kayes, and from the Soninké ethnic group. Gubert (2000) provides a thorough historical picture of Soninké migration since the pre-colonial era. She shows that the historical features of Soninké migration during the pre-colonial and colonial eras are the ground for today's Malian migration. To capture this historical background that paved the way for current movements of emigration in Mali, we compute the distance of each Malian locality to the traditional Soninké migratory route. This traditional route is provided by Pollet and Winter (1971). While this variable should reflect the historical heritage of the Malian migratory phenomenon, the distance to Bamako, which is nowadays the pivotal point of most migration flows, is added to capture the current access to migration route. We add three more instruments when splitting the RETURNEES variable into returnees from Africa and returnees from the rest of the world: the distance to the city of Kayes, main pivotal point of the migration flows directed towards non-African countries, and the distance to the main destination country, respectively in Africa and in the rest of the world: Côte d'Ivoire and France.

Columns (3) and (4) show the second-steps of the fixed-effects instrumental variables estimations (full results are presented in Annex C). The estimated impact of RETURNEES is 
found to be insignificant, with satisfying instrumentation tests. The results of column (4) urge us to remain cautious, since the first-step F-tests are rather low and the sizes of the coefficients for RETURNEES - AFRICA and RETURNEES - REST OF THE WORLD are higher than in the benchmark estimation. However, the signs and statistical significance of the two coefficients of interest are unchanged, confirming the positive impact of returnees coming back from non-African countries on participation rates and the statistically not significant impact of returnees from African countries.

[Table 5 around here]

\section{A transfer of political norms?}

These results seem to confirm that Malian returnees coming back from non-African countries have a positive and significant impact on participation rates in the localities where they settle, while we do not find a robust significant effect of returnees coming back from African countries. This is in line with the previous literature, especially with Batista and Vicente (2011) and Mahmoud et al. (2012) who find that returnees from countries with better governance tend to increase the demand for accountability and the probability of political change.

But so far our estimations do not directly test a transfer of political norm. Indeed, we observe a statistical correlation between the share of returnees from non-African countries and the participation rates, which may be due to the fact that return migrants have a higher propensity to vote, rather than to a diffusion of norms. We design three supplementary tests at the level of the localities which results advocate for a likely transfer of political norm.

As a preliminary check, in columns (1) and (2) of Table 6, we introduce as a control variable the share of intra-Mali return migrants, INTERNAL RETURNEES. Indeed, we may 
wonder whether returnees have an impact on participation because they moved to a foreign country, where they may have acquired new types of electoral norms, or simply because they moved. The data on internal migration come from RGPH (INSTAT, 1998 and 2009). The share of intra-Mali returnees measures the proportion of the population of the locality aged over eighteen that declares having settled in a different cercle $^{15}$ during more than six months. We find that INTERNAL RETURNEES has a positive though not significant impact on participation, while the estimated coefficient for returnees from non-African countries remains significantly positive and very close from the benchmark estimate (column (4), Table 4). This suggests that the correlation between returnees and participation rates is explained by the fact that returnees moved to non-African foreign countries, rather than simply moved from their locality.

Second, we design a test to check for the existence of a spillover effect from migrants coming back from non-African countries, to non-migrants. Given that electoral results are available only at the locality level, we cannot run individual-level regressions to directly estimate the impact of returnees on their relatives and neighbouring non-migrant households. In order to explore this diffusion effect we focus on the 41 localities of the sample that do not count any returnees from non-African countries, neither in 1998 nor in 2009, and look at the impact on their participation rate of the share of returnees from non-African countries of the most migrant-intensive neighbouring locality. Neighbouring localities refer to pairs of localities sharing a common border. For each of the 41 localities of the sub-sample, we identify its neighbouring localities and pick the one that counts the most important stock of returnees from non-African countries. We introduce in the estimation the stock of returnees of this neighbour. We also control for the participation rate of the neighbour to account for other potential sources of diffusion effects. With or without the participation rate of the neighbour,

\footnotetext{
${ }^{15}$ The Malian territory is divided in 8 regions, plus Bamako. Each region counts villages, gathered within 703 communes, themselves gathered within 49 cercles.
} 
the results are not changed. Note that because the estimations are run on the sample of locality with no return migrants from non-African countries, the variable RETURNEES - REST OF THE WORLD is dropped.

Results are shown in Column (3) of Table 6. The share of returnees in the neighbourhood has a large, positive and significant impact on participation in localities with no returnees from non-African countries. This effect of the neighbourhood suggests that returnees are likely to trigger the diffusion of new electoral norms. Finally, in Column (4) we run the same estimation, but adding the share of returnees from African countries observed in the neighbouring locality that counts the higher proportion of those returnees in its population. We observe that African returnees in the neighbourhood do not affect participation, while the share of returnees from non-African countries in the neighbourhood still strongly impacts participation in the localities with no returnees from non-African countries. These two estimations on the sub-sample of the localities that do not count any returnees from nonAfrican countries suggest that political norms may indeed spill over from one locality to the other.

[Table 6 around here]

Finally, we compare to the gain associated with the presence of returnees as suggested by the coefficients in regression (4) of Table 4 to the gain simulated under the assumption that all the returnees vote. We focus on the impact of returnees from non-African countries, as suggested by the benchmark results. Thus we assume that return migrants from Africa and non-migrants have the same electoral behaviours on average. 
Assuming that returnees from non-African countries have a participation rate of $100 \%$, given the observed participation rate of the locality we can compute for each locality the simulated participation rate of non-migrants (and returnees from African countries):

$$
\begin{aligned}
& \text { Participation of non migrants and returnees from } \text { Africa }_{c, t} \\
& =\frac{\left(\text { ObservedParticipation }_{c, t}-\text { Share of returnees from the rest of the } \text { world }_{c, t}\right)}{\text { Share of non migrants and returnees from Africa }}
\end{aligned}
$$

We then calculate the difference between the observed participation and this simulated participation of the non-migrants: this difference reflects the net gain, in terms of participation, of having all the returnees voting. We refer to this gain as Gain A. We find that, among our sample, the average of Gain A equals 0.0019 .

In a second step, we derive from our econometric model the predicted gain, in terms of participation, associated to the presence of return migrants. This is computed as the share of RETURNEES - REST OF THE WORLD of each locality multiplied by the coefficient of this variable in regression (4) of Table 4 (0.807). We refer to this gain as Gain B. The average value of Gain B, among the sample, is 0.0029 .

Finally, we compare the predicted gain in terms of participation associated with the presence of returnees (Gain B), with the simulated gain in terms of participation associated with having all the returnees voting (Gain A). Table 7 presents descriptive statistics for the difference between Gain B and Gain A. When positive, this difference means that the predicted gain in terms of participation associated with the presence of returnees is larger than the simulated gain in terms of participation associated with the assumption that all returnees from non-African countries vote. This comparison shows that in $99 \%$ of the 1,394 localities of the sample, the predicted gain associated to the presence of returnees is greater than the simulated gain associated to the vote of all the returnees. This is another evidence of a 
diffusion of political norms from returnees to non-migrants: the participation rate increases more than it would if all the returnees from non-African countries, individually, voted.

[Table 7 around here]

\section{Returnees and the characteristics of the localities}

So far, our results support the hypothesis of a transfer of political norms from returnees to their communities of origin when returnees experience a very different environment abroad. When they come back from non-African countries, returnees tend to influence people's participation behaviours. This suggests that while being abroad migrants become more sensitive to political matters and participation. This form of knowledge may compensate for the absence of education of the non-migrants, in which case it would indirectly confirm that the impact of returnees on electoral outcome comes from a transfer of political norms. To test this hypothesis, we examine whether the impact of returnees differs according to the average level of education in the locality. More specifically, the stock of returnees is introduced in interaction with the literacy rate, the percentage of primary, secondary and tertiary educated people in the locality. All the education variables are calculated as the proportion of the nonmigrant population aged eighteen and above. The results of these estimations are shown in Table 8.

Column (1) presents the impact of the interaction between the stock of returnees and the literacy rate of the locality. The results suggest a significantly positive direct impact of RETURNEES, and a significantly negative impact of its interaction with the literacy rate in the locality. Thus the stock of returnees has a positive impact on participation, but its impact is reduced as the locality presents a growing share of literate individuals. This adverse effect 
of the interaction between RETURNEES and LITERACY suggests a substitution effect, regarding turnout, between the literacy of the non-migrants and the presence of returnees.

Column (2) disaggregates return migrants from Africa and from the rest of the world. The results for RETURNEES - AFRICA are very close to the results of column (1): we find a significantly positive direct effect of the share of returnees from Africa on participation, and a significantly negative effect of its interaction with LITERACY. Returnees from Africa positively affect turnout where literacy of non-migrants is low. Taking into account this interaction term we find that the total impact of returnees from African countries is positive when the literacy rate of the locality does not exceed $12.6 \%$, which is the case of $57 \%$ of the observations in our sample. Finally, we do not observe any significant effect of the interaction between RETURNEES - REST OF THE WORLD and LITERACY. This suggests that the impact of returnees from non-African countries does not vary depending on the percentage of literate people in the locality.

Turning to primary education in columns (3) and (4), the results remain similar regarding RETURNEES and RETURNEES - AFRICA, even if the direct positive impact of the two variables loses significance. The p-values for the joint significance of these variables with the interaction term are respectively 0.0715 and 0.0961 . We find that the level of primary education below which RETURNEES - AFRICA has a positive influence on the participation rate is $4.2 \%$, which accounts for around $39 \%$ of the localities. In Column (4), RETURNEES REST OF THE WORLD has now a positive influence on the participation rate which significantly depends on the level of primary education in the locality ( $p$-value for joint significance $=0.0078$ ). When the percentage of primary educated people in the locality is lower than $11.6 \%$, which is the case of $87.5 \%$ of the localities in our sample, then the share of returnees from non-African countries has a strong positive impact. It decreases as the share of 
primary educated people increases. The relationship between primary education and the impact of RETURNEES - REST OF THE WORLD is depicted in Figure 3.

[Figure 3 around here]

Columns (5) to (8) show that the substitution effect between the knowledge acquired during migration and the level of education within non-migrants disappears for higher levels of education (SECONDARY and TERTIARY), while the direct impact of RETURNEES REST OF THE WORLD remains positive and significant.

[Table 8 around here]

Table 8 thus suggests a positive correlation between returnees from non-African countries and participation rates, which may notably compensate for the lack of primary education in the locality. Our results also show that returnees from African countries are positively correlated with participation, but their impact becomes smaller as the literacy rate and primary education of the locality grow. Overall, this suggests the existence of a substitution effect between education of the non-migrants and the presence of returnees. This substitution effect is mainly important for returnees from non-African countries and primary education, and, to a lesser extent, between returnees from African countries and literacy rate as well as primary education. The substitution effect disappears for higher levels of education. 


\section{Going further the impact on participation}

So far we found suggestive evidence of a transfer of political norms from returnees to their home communities, regarding electoral participation. This last section is dedicated to extend the analysis to political outcomes other than the participation rate. Indeed, if returnees transmit norms of participation, they may also affect the nature of the votes. To investigate this question, we rely on the same econometric model as in Section 5, and change the dependant variable. Three alternative political outcomes are tested, all of them being calculated for the local elections of 1998/1999 and 2009:

- MAJ: the share of votes obtained by the elected majority. In our sample, this variable ranges from 0.17 to 1 .

- FRAG: the index of political fragmentation, computed relying on the share of votes obtained by each competing party. It is one minus the Herfindhal index, i.e. the sum of the squared shares of votes obtained by each party. It ranges from 0 to 1,0 indicating a total domination of one single party. Fragmentation increases when FRAG gets closer to one, indicating a larger dispersion of the votes between the lists in the race.

- GAP: the difference between the shares of votes obtained by the first and by the second lists. The victory of the winner is larger as GAP increases.

These three dependant variables capture the competitiveness of the electoral race ex-post. Table 9 presents the results, both for the global stock of returnees (columns (1)-(3)) and for the stocks of returnees coming back from African and non-African countries (columns (4)$(6))$.

We find a significant impact of the global stock of returnees on the three different outcomes. Returnees are found to be positively correlated with political fragmentation, and negatively with the size of the majority and with the difference between the shares of votes 
obtained by the first and second lists. Thus, localities with a larger stock of returnees are also characterized by higher levels of political fragmentation, smaller majorities, and lower gaps between the winner and the challenger. These three results are very consistent with each other: they all suggest that the stock of returnees enhances the competitiveness of local elections.

In the last three columns, we distinguish between returnees from Africa and returnees from the rest of the world. We observe that the global impact of RETURNEES is indeed mainly driven by returnees coming back from non-African countries. Despite the fact that the coefficients for RETURNEES - AFRICA all have the same signs as those for RETURNEES and RETURNEES - REST OF THE WORLD, they are never significant (though its p-value equals 0.109 in column (5)). Thus, return migrants have a significant and positive impact on electoral competitiveness, which mainly transits through returnees coming back from nonAfrican countries. Similar results are found in (unreported) pooled OLS estimations. The full results including the control variables are presented in Annex D.

[Table 9 around here]

\section{Conclusion}

This paper investigates the impact of return migration on electoral behaviours in Mali. We use a panel dataset combining the Malian censuses of 1998 and 2009 and electoral results at the locality level for the municipal elections of 1998/1999 and 2009. Through this study, we test for the existence of a transfer of political norms from returnees to their communities of origin. We find evidence that returnees from non-African countries have a significant and positive impact on participation rates. This suggests that migrants who experienced very different economic and political environments during their migration bring different political 
norms back home and are susceptible to influence non-migrants electoral behaviours. Various robustness checks confirm this result, first addressing the endogeneity issues and secondly testing for the existence of a diffusion effect from returnees to non-migrants. Moreover, we put forward a substitution effect between the presence of returnees and the level of education of non-migrants: the impact of returnees on participation is more important where nonmigrants are poorly educated, returnees from non-African countries substituting for higher levels of education than returnees from Africa.

In a last step, we explore the impact of returnees on three alternative dependent variables that reflect the competitiveness of the local elections: the size of the elected majority, the political fragmentation which indicates the dispersion of the votes between the different competing lists, and the difference between the shares of votes obtained by the winner party and by the challenger. We put forward a significant impact of the stock of returnees from nonAfrican countries on those three variables. A significantly higher electoral competitiveness is observed in the localities with a higher share of returnees from non-African countries. The impact of returnees from Africa goes in the same direction but is not statistically significant. 


\section{References}

Ashenfelter, O. and S. Kelley Jr., 1975, "Determinants of Participation in Presidential Elections". Journal of Law and Economics, Vol. 18: 695.

Batista, C., T. McIndoe-Calder and P.C. Vicente, 2010, "Return Migration, Entrepreneurship and Self-Selection", Trinity College, Dublin.

Batista, C. and P.C. Vicente, 2010, "Do Migrants Improve Governance at Home? Evidence from a Voting Experiment". The World Bank Economic Review 25 (1): 77-104.

Beine, M., F. Docquier and M. Schiff, 2012, "International Migration, Transfers of Norms and Home Country Fertility". Forthcoming in the Canadian Journal of Economics.

Beine, M. and K. Sekkat, 2011, "Skilled migration and the transfer of institutional norms" . Mimeo.

Belsley, D.A., E. Kuh and R.E. Welsch, 1980, "Regression diagnostics: Identifying influential data and sources of collinearity". Wiley New York.

Bertoli, S. and F. Marchetta, 2012, "Bringing it All Back Home. Return Migration and Fertility Choices". Working Paper "Etudes et Documents” E2012.1, Centre d'Etudes et de Recherches sur le Développement International, Clermont-Ferrand. 
Blais, A. and A. Dobrzynska, 1998, “Turnout in Electoral Democracies”. European Journal of Political Research 33(2): 239-261.

Bossuroy, T. 2007, "Voting in an African Democracy: Does only Ethnicity Rule?”. EHESS, Paris School of Economics, DIAL, mimeo.

Bratton M., M. Coulibaly and F. Machado, 2002, "Popular Views of the Legitimacy of the State in Mali”. Canadian Journal of African Studies 36(2): 197-238.

CERPOD (Centre d'Etudes et de Recherches sur la Population et le développement), 1996, Réseau migration et urbanisation en Afrique de l'Ouest, 1996, Enquêtes maliennes sur les migrations et l'urbanisation (EMMU) 1992-1993.

Dedieu, J.P., L. Chauvet, F. Gubert and S. Mesplé-Somps, 2012, "Political Transnationalism. The case of the Senegalese Presidential Elections in France and New-York". DIAL, mimeo.

Démurger, S. and H. Xu, 2011, "Return migrants: The rise of new entrepreneurs in rural China." World Development 39 (10):1847-1861.

Diabaté, I. and S. Mesplé-Somps, 2012, "Migration et transferts de normes : le cas des pratiques d'excision au Mali'. DIAL, mimeo.

Docquier, F., E. Lodigiani, H. Rapoport and M. Schiff, 2011, "Emigration and democracy". IZA Discussion Paper $\mathrm{n}^{\circ} 5496$. 
Dunning T., Harrison L. 2010, “Cross-Cutting Cleavages and Ethnic Voting: An

Experimental Study of Cousinage in Mali." American Political Science Review 104 (1): 1-19.

Dustmann, C. and O. Kirchkamp, 2002, “The optimal migration duration and activity choice after re-migration”. Journal of Development Economics 67 (2):351-372.

Fidrmuc, J. and O. Doyle, 2006, "Does Where You Live affect How You Vote? An Analysis of Migrant Voting Behavior”. Uxbridge: Brunel Business School.

Gubert F. 2000, Migration as a collective risk-coping strategy. Evidence from the Kayes area (Western Mali). Ph.D. thesis, University of Auvergne.

Highton B. 2000, "Residential Mobility, Community Mobility, and Electoral Participation”. Political Behavior 22(2): 109-120.

Hildebrandt, N. and D.J. McKenzie, , 2005, "The Effects of Migration on Child Health in Mexico". Journal of LACEA Economia, LACEA - LATIN AMERICAN AND CARIBBEAN ECONOMIC ASSOCIATION.

Li X. and J. McHale, 2006, "Does brain drain lead to institutional gain? A cross country empirical investigation". Manuscript: Queen University.

Lindstrom, D.P. and S.G. Saucedo, 2002, "The short-and long-term effects of US migration experience on Mexican women's fertility”. Social Forces 80 (4):1341-1368. 
Lodigiani, E. and S. Salomone, 2012, "Migration-induced Transfers of Norms. The case of Female Political Empowerment”. Université catholique de Louvain, Institut de Recherches Economiques et Sociales (IRES).

Mahmoud, O., H. Rapoport, A. Steinmayr, and C. Trebesch, 2012, "Emigration and Political Change". Mimeo.

Marshall, M.G. and K. Jaggers, 2005, "POLITY IV project: Political Regime Characteristics and Transitions, 1800-2004". http://www.systemicpeace.org/inscr/inscr.htm

Mesnard, A., 2004, "Temporary migration and self-employment: evidence from Tunisia". Brussels Economic Review 47 (1):119-138.

Ndione B., Lombard J. 2004, “Diagnostic des projets de réinsertion économique des migrants de retour : étude de cas au Mali (Bamako, Kayes)". Revue européenne des migrations internationales 20(1): 169-195.

Oliver JE., 2000, "City Size and Civic Involvement in Metropolitan America". American Political Science Review 94: 361-373.

Pérez-Armendariz, C. and D. Crow, 2010, "Do migrants remit democracy? International migration, political beliefs, and behavior in Mexico". Comparative political studies 43 (1):119-148. 
Pfutze T., 2012, "Does Migration Promote Democratization? Evidence from the Mexican transition". Journal of Comparative Economics 40 (2):159-175.

Piracha, M. and F. Vadean, 2010, "Return migration and occupational choice: Evidence from Albania”. World Development 38 (8):1141-1155.

Pollet, E. and G. Winter, 1971, La société Soninké (Dyahunu, Mali). Editions de l'Institut de sociologie, Université libre de Bruxelles.

Powell GB., 1984, Comparative Democracies: Participation, Stability and Violence.

Cambridge, MA: Harvard University Press.

Sandbrook R., 1996, “Transitions without Consolidation: Democratization in Six African Cases". Third World Quarterly 17(1): 69-87.

Spilimbergo A., 2009, "Democracy and foreign education”. American Economic Review 99(1): 528-43.

Welsch, R.E. and E. Kuh, 1977, "Linear regression diagnostics”. National Bureau of Economic Research Cambridge, Mass., USA. 
Table 1. Local and national elections in Mali, 1992-2009.

\begin{tabular}{|c|c|c|c|c|c|c|c|c|c|c|c|}
\hline & Presidential & Legis. & Presidential & Legis. & Local & Presidential & Legis. & Local & Presidential & Legis. & Local \\
\hline Year & 1992 & 1992 & 1997 & 1997 & 1998-99 & 2002 & 2002 & 2004 & 2007 & 2007 & 2009 \\
\hline Rounds & 2 & 2 & 1 & 2 & 1 & 2 & 2 & 1 & 1 & 2 & 1 \\
\hline $\begin{array}{l}\text { Participation } \\
\text { rate }(\%)\end{array}$ & $23.6 \% / 20.9 \%$ & $\sim 21 \%$ & $28.4 \%$ & $\sim 21.6 \%$ & $36 \%$ & $38.3 \% / 30 \%$ & 22.7\%/n.a. & $41.6 \%$ & $36.2 \%$ & 31.5\%/n.a. & $41.7 \%$ \\
\hline $\begin{array}{l}\text { Winner } \\
\text { (party) } \\
{[\%]}\end{array}$ & $\begin{array}{l}\text { Konaré } \\
\text { (ADEMA) } \\
{[44.9 \% / 69 \%]}\end{array}$ & ADEMA & $\begin{array}{l}\text { Konaré } \\
\text { (ADEMA) } \\
{[95.9 \%]}\end{array}$ & ADEMA & - & $\begin{array}{l}\text { Touré } \\
{[28.7 \% /} \\
64.3 \%]\end{array}$ & $\begin{array}{l}\text { Espoir } 2002 \\
{[26.3 \% /} \\
44.8 \%]\end{array}$ & - & $\begin{array}{l}\text { Touré } \\
(A D P) \\
{[71.2 \%]}\end{array}$ & $\begin{array}{l}A D P \\
\text { [n.a./ } \\
76.9 \% \text { ] }\end{array}$ & - \\
\hline $\begin{array}{l}\% \text { of } \\
\text { communes } \\
\text { where } \\
\text { ADEMA is } \\
\text { dominant }\end{array}$ & n.a. & n.a. & n.a. & n.a. & $76.4 \%$ & n.a. & $42.5 \%$ & $36.7 \%$ & n.a. & $32.4 \%$ & $40 \%$ \\
\hline $\begin{array}{l}\% \text { of votes } \\
\text { for ADEMA }\end{array}$ & $44.9 \% / 69 \%$ & n.a. & $95.9 \%$ & n.a. & $53.9 \%$ & $21.3 \% / 35.7 \%$ & $\begin{array}{l}\text { ADEMA } \\
\text { part of } A R D\end{array}$ & $24.5 \%$ & $\begin{array}{l}\text { ADEMA } \\
\text { part of } A D P\end{array}$ & $\begin{array}{l}\text { ADEMA } \\
\text { part of } A D P\end{array}$ & $29.7 \%$ \\
\hline $\begin{array}{l}\% \text { of NA } \\
\text { seats } \\
\text { obtained by } \\
\text { ADEMA }\end{array}$ & - & $65.5 \%$ & - & $87.1 \%$ & - & - & $30.6 \%$ & - & - & $34.7 \%$ & - \\
\hline
\end{tabular}

"Legis." to legislative elections.

Sources: Electoral data for the local and legislative and presidential elections from 1999 on. Completed using the African Election Database (available at

http://africanelections.tripod.com $/ \mathrm{ml} . \mathrm{html}$ ) for the presidential elections and for the elections prior to 1999. 
Table 2. Malian emigrants in the world, 1995 and 2001.

\begin{tabular}{l|c|c|c|c}
\hline \multirow{2}{*}{ Geographic Areas } & \multicolumn{2}{|c|}{ Number of migrants } & \multicolumn{2}{c}{$\%$ of the migrants } \\
\cline { 2 - 5 } & 1995 & 2001 & 1995 & 2001 \\
\hline Europe & 102,000 & 156,100 & 2.7 & 5.8 \\
America & 1,705 & 6,000 & 0.1 & 0.2 \\
Asia & 26,550 & 101,250 & 0.7 & 3.8 \\
Africa & $3,627,305$ & $2,419,875$ & 96.5 & 90.2 \\
\hline \multicolumn{1}{c}{ of which West Africa } & $2,961,500$ & $2,156,000$ & 81.6 & 89.1 \\
\hline Total & $3,757,560$ & $2,683,235$ & 100.0 & 100.0 \\
\hline
\end{tabular}

Source: Censuses of abroad-living Malians, MAEMEIA 1996 and MAEIA 2002. 
Table 3. Composition of the share of returnees by destination.

\begin{tabular}{r|c|c}
\hline Share of returnees (in percent) from: & 1998 & 2009 \\
\hline Africa & 95.70 & 87.38 \\
\hline Among which & & \\
Côte d'Ivoire & 59.02 & 61.52 \\
Burkina Faso & 8.51 & 7.28 \\
Senegal & 6.57 & 5.99 \\
Mauritania & 4.86 & 2.62 \\
Guinea & 5.41 & 4.09 \\
Niger & 3.25 & 2.12 \\
Gabon & 2.39 & 3.38 \\
Ghana & 2.18 & 1.56 \\
Congo Brazzaville & 1.76 & 2.41 \\
Other & 6.05 & 9.03 \\
\hline Non-African Countries & 4.30 & 12.62 \\
\hline Among which & & \\
Europe & & 56.78 \\
France & 64.82 & 24.14 \\
Spain & & 2.00 \\
Russia & 3.25 & 0.88 \\
America & & 12,48 \\
USA & 3.30 & 2.44 \\
Asia & & 26,61 \\
China & 0.71 & 5.67 \\
Saudi Arabia & & 4.73 \\
Israel & & 2.34 \\
Kazaghstan & & 2.11 \\
Other & 27.92 & 4.13 \\
\hline
\end{tabular}

Source: authors' calculation using RGPH 1998 and 2009. 
Table 4. Returnees and participation, benchmark estimations.

\begin{tabular}{|c|c|c|c|c|}
\hline \multirow[t]{2}{*}{$\begin{array}{l}\text { Dependent: } \\
\text { PARTICIPATION }\end{array}$} & (1) & (2) & (3) & (4) \\
\hline & Pooled OLS & Fixed Effects & Pooled OLS & Fixed Effects \\
\hline RETURNEES & $\begin{array}{l}0.0945^{*} \\
(0.0518)\end{array}$ & $\begin{array}{l}0.0473 \\
(0.136)\end{array}$ & & \\
\hline RETURNEES - AFRICA & & & $\begin{array}{c}0.0786 \\
(0.0516)\end{array}$ & $\begin{array}{l}0.0171 \\
(0.138)\end{array}$ \\
\hline \multicolumn{2}{|c|}{ RETURNEES - REST OF THE WORLD } & & $\begin{array}{c}0.787 * * * \\
(0.244)\end{array}$ & $\begin{array}{l}0.807^{* *} \\
(0.404)\end{array}$ \\
\hline LISTS & $\begin{array}{l}-0.000842 \\
(0.00123)\end{array}$ & $\begin{array}{l}-0.00146 \\
(0.00159)\end{array}$ & $\begin{array}{l}-0.000689 \\
(0.00123)\end{array}$ & $\begin{array}{l}-0.00150 \\
(0.00159)\end{array}$ \\
\hline INITIAL PARTICIPATION & $\begin{array}{c}0.615 * * * \\
(0.0183)\end{array}$ & & $\begin{array}{c}0.616 * * * \\
(0.0183)\end{array}$ & \\
\hline POPULATION (LOG) & $\begin{array}{c}-0.0224 * * * \\
(0.00349)\end{array}$ & $\begin{array}{l}-0.0126 \\
(0.0294)\end{array}$ & $\begin{array}{l}-0.0222^{* * *} \\
(0.00349)\end{array}$ & $\begin{array}{l}-0.0123 \\
(0.0294)\end{array}$ \\
\hline LITERACY & $\begin{array}{l}0.0845^{(a)} \\
(0.0527)\end{array}$ & $\begin{array}{c}0.100 \\
(0.152)\end{array}$ & $\begin{array}{l}0.0868 * \\
(0.0526)\end{array}$ & $\begin{array}{c}0.104 \\
(0.152)\end{array}$ \\
\hline WEALTH & $\begin{array}{c}-0.0165 * * * \\
(0.00506)\end{array}$ & $\begin{array}{c}-0.0356^{* *} \\
(0.0155)\end{array}$ & $\begin{array}{c}-0.0179 * * * \\
(0.00509)\end{array}$ & $\begin{array}{c}-0.0371 * * \\
(0.0153)\end{array}$ \\
\hline RAIN SHOCKS & $\begin{array}{c}-0.000680 * * * \\
(0.000240)\end{array}$ & $\begin{array}{l}-0.000461 \\
(0.000429)\end{array}$ & $\begin{array}{c}-0.000743 * * * \\
(0.000243)\end{array}$ & $\begin{array}{l}-0.000442 \\
(0.000428)\end{array}$ \\
\hline PEUL/FOULFOULBE & $\begin{array}{l}0.00894 \\
(0.0103)\end{array}$ & $\begin{array}{c}0.235 \\
(0.183)\end{array}$ & $\begin{array}{c}0.0104 \\
(0.0104)\end{array}$ & $\begin{array}{c}0.233 \\
(0.183)\end{array}$ \\
\hline SONRAI/DJEMA & $\begin{array}{l}0.0305^{* * *} \\
(0.0109)\end{array}$ & $\begin{array}{c}0.819^{* *} \\
(0.390)\end{array}$ & $\begin{array}{c}0.0304 * * * \\
(0.0109)\end{array}$ & $\begin{array}{l}0.811^{* *} \\
(0.391)\end{array}$ \\
\hline MARAKA/SONINKE & $\begin{array}{l}0.00210 \\
(0.0113)\end{array}$ & $\begin{array}{c}0.370 \\
(0.228)\end{array}$ & $\begin{array}{l}-0.0121 \\
(0.0122)\end{array}$ & $\begin{array}{c}0.359 \\
(0.228)\end{array}$ \\
\hline DOGON & $\begin{array}{c}0.0417 * * * \\
(0.00815)\end{array}$ & $\begin{array}{c}0.131 \\
(0.318)\end{array}$ & $\begin{array}{c}0.0405^{* * *} \\
(0.00813)\end{array}$ & $\begin{array}{c}0.140 \\
(0.319)\end{array}$ \\
\hline MAURE/ARABE & $\begin{array}{l}-0.0229 \\
(0.0558)\end{array}$ & $\begin{array}{l}0.0766 \\
(0.401)\end{array}$ & $\begin{array}{l}-0.0206 \\
(0.0546)\end{array}$ & $\begin{array}{l}0.0565 \\
(0.401)\end{array}$ \\
\hline TAMACHEQ & $\begin{array}{l}-0.0252 \\
(0.0233)\end{array}$ & $\begin{array}{c}0.388 \\
(0.348)\end{array}$ & $\begin{array}{l}-0.0289 \\
(0.0234)\end{array}$ & $\begin{array}{c}0.376 \\
(0.349)\end{array}$ \\
\hline MINIANKA & $\begin{array}{c}0.0511^{* * *} \\
(0.00846)\end{array}$ & $\begin{array}{c}0.172 \\
(0.117)\end{array}$ & $\begin{array}{l}0.0519 * * * \\
(0.00840)\end{array}$ & $\begin{array}{c}0.178 \\
(0.115)\end{array}$ \\
\hline OTHER & $\begin{array}{c}0.0144 \\
(0.00880)\end{array}$ & $\begin{array}{c}0.226 \\
(0.162)\end{array}$ & $\begin{array}{c}0.0127 \\
(0.00881)\end{array}$ & $\begin{array}{c}0.216 \\
(0.161)\end{array}$ \\
\hline YEAR 2009 & $\begin{array}{l}0.105 * * * \\
(0.00693)\end{array}$ & $\begin{array}{c}0.116^{* * * *} \\
(0.0150)\end{array}$ & $\begin{array}{l}0.102 * * * \\
(0.00710)\end{array}$ & $\begin{array}{c}0.115 * * * \\
(0.0151)\end{array}$ \\
\hline Constant & $\begin{array}{l}0.452 * * * \\
(0.0441)\end{array}$ & $\begin{array}{c}0.593 * * \\
(0.283)\end{array}$ & $\begin{array}{l}0.461 * * * \\
(0.0442)\end{array}$ & $\begin{array}{l}0.602 * * \\
(0.283)\end{array}$ \\
\hline
\end{tabular}


Table 4. Returnees and participation, benchmark estimations (continued).

\begin{tabular}{lcccc}
\hline Observations & 1,394 & 1,394 & 1,394 & 1,394 \\
R-squared & 0.621 & 0.369 & 0.623 & 0.372 \\
Number of localities & 697 & 697 & 697 & 697 \\
Localities fixed effects & NO & YES & NO & YES \\
\hline
\end{tabular}

Notes: Robust standard errors clustered within localities in parentheses. ${ }^{* * *} \mathrm{p}<0.01,{ }^{* *} \mathrm{p}<0.05,{ }^{*} \mathrm{p}<0.1$.

(a): $\mathrm{p}=0.109$.

Columns (1) and (3) present Pooled OLS estimations, columns (2) and (4) present fixed-effects estimations.

PARTICIPATION is participation rate, referring to the 1998/1999 and 2009 local elections. RETURNEES is the stock of return migrants aged over 18 over the total population of the locality aged over 18. RETURNEES AFRICA (respectively REST OF THE WORLD) is the stock of return migrants from African (respectively nonAfrican) countries aged over 18 over the total population of the locality aged over 18. LISTS is the number of lists in the current election; POPULATION is the logarithm of the locality's population aged 18 and more LITERACY is the share of the population of the locality aged over 18 that is literate ; WEALTH is a composite index of the wealth per capita of the locality; RAIN SHOCKS is the standard deviation of the rain shocks over the ten years preceding the ballot; and PEUL/FOULFOULBE - OTHER are the share of the population aged over 18 of each ethnic group in the locality (based on spoken language). 
Table 5. Addressing the endogeneity bias.

\begin{tabular}{|c|c|c|c|c|}
\hline \multirow[t]{3}{*}{ Dependant : PARTICIPATION } & (1) & (2) & (3) & (4) \\
\hline & \multicolumn{2}{|c|}{$\begin{array}{c}\text { BACK WHERE THEY WERE } \\
\text { BORN }\end{array}$} & \multicolumn{2}{|c|}{ IV procedure } \\
\hline & \multicolumn{2}{|c|}{ Fixed effect estimations } & \multicolumn{2}{|c|}{ Fixed effects TSLS } \\
\hline $\begin{array}{l}\text { RETURNEES } \\
\text { RTR }\end{array}$ & $\begin{array}{l}-0.0768 \\
(0.141)\end{array}$ & & $\begin{array}{l}-0.388 \\
(0.669)\end{array}$ & \\
\hline \multicolumn{2}{|l|}{ RETURNEES - AFRICA } & $\begin{array}{l}-0.181 \\
(0.147)\end{array}$ & & $\begin{array}{l}-1.157 \\
(0.780)\end{array}$ \\
\hline \multicolumn{2}{|c|}{ RETURNEES - REST OF THE WORLD } & $\begin{array}{l}2.310 * * * \\
(0.799)\end{array}$ & & $\begin{array}{l}7.491^{*} \\
(4.164)\end{array}$ \\
\hline \multicolumn{5}{|l|}{ Instrumentation tests } \\
\hline \multicolumn{2}{|l|}{ First stage F-test RETURNEES } & & \multicolumn{2}{|l|}{12.10} \\
\hline \multicolumn{3}{|c|}{ First stage F-test RETURNEES - AFRICA } & & 8.17 \\
\hline \multicolumn{3}{|c|}{ First stage F-test RETURNEES - ROW } & & 3.77 \\
\hline \multicolumn{3}{|l|}{ Underidentification test } & 0.0000 & 0.0066 \\
\hline \multicolumn{3}{|l|}{ Overidentification test } & 0.7323 & 0.7862 \\
\hline Observations & 1,394 & 1,394 & 1,394 & 1,394 \\
\hline R-squared & 0.370 & 0.375 & 0.359 & 0.137 \\
\hline Number of localities & 697 & 697 & 697 & 697 \\
\hline Localities fixed-effects & YES & YES & YES & YES \\
\hline Control variables & YES & YES & YES & YES \\
\hline
\end{tabular}

Notes: Robust standard errors clustered within localities in parentheses. ${ }^{* * *} \mathrm{p}<0.01,{ }^{* *} \mathrm{p}<0.05,{ }^{*} \mathrm{p}<0.1$. Fixed-effects estimations.

All control variables of the baseline estimation (Table 4) are included. PARTICIPATION is participation rate, referring to the 1998/1999 and 2009 local elections. RETURNEES is the stock of return migrants aged over 18 over the total population of the locality aged over 18. RETURNEES - AFRICA (respectively REST OF THE WORLD) is the stock of return migrants from African (respectively non-African) countries aged over 18 over the total population of the locality aged over 18.

Columns (1) and (2) present the second-step of instrumental estimations, using the distances to Bamako and to the traditional migratory route as instruments for RETURNEES, and the distances to Bamako, to the traditional migratory route, to Kayes, to Côte d'Ivoire and to France for RETURNEES - AFRICA and RETURNEES - REST OF THE WORLD. Distances are interacted with a period indicator. The full results are presented in Annex C. 
Table 6. Testing for a diffusion effect - Fixed effects estimations.

\begin{tabular}{|c|c|c|c|c|}
\hline \multirow[t]{2}{*}{ Dependent : PARTICIPATION } & \multirow{2}{*}{\multicolumn{2}{|c|}{$\begin{array}{l}(1) \quad(2) \\
\text { Internal migration }\end{array}$}} & \multirow{2}{*}{\multicolumn{2}{|c|}{$\begin{array}{l}(3) \quad(4) \\
\text { Diffusion effect }\end{array}$}} \\
\hline & & & & \\
\hline RETURNEES & $\begin{array}{l}0.0285 \\
(0.136)\end{array}$ & & & \\
\hline RETURNEES - AFRICA & & $\begin{array}{c}-0.000795 \\
(0.137)\end{array}$ & $\begin{array}{l}-0.240 \\
(0.392)\end{array}$ & $\begin{array}{l}-0.390 \\
(0.525)\end{array}$ \\
\hline RETURNEES - REST OF THE WORLD & & $\begin{array}{l}0.794 * \\
(0.413)\end{array}$ & & \\
\hline INTERNAL RETURNEES & $\begin{array}{c}0.0221 \\
(0.0237)\end{array}$ & $\begin{array}{c}0.0218 \\
(0.0238)\end{array}$ & & \\
\hline RETURNEES - AFRICA: NEIGHBOUR & & & & $\begin{array}{l}-0.179 \\
(0.784)\end{array}$ \\
\hline RETURNEES - ROW: NEIGHBOUR & & & $\begin{array}{c}1.750 * * \\
(0.795)\end{array}$ & $\begin{array}{c}1.892 * * \\
(0.885)\end{array}$ \\
\hline PARTICIPATION RATE: NEIGHBOUR - ROW & & & $\begin{array}{l}-0.018 \\
(0.206)\end{array}$ & $\begin{array}{l}-0.166 \\
(0.198)\end{array}$ \\
\hline PARTICIPATION RATE: NEIGHBOUR - AFRICA & & & & $\begin{array}{c}0.424 \\
(0.288) \\
\end{array}$ \\
\hline Observations & 1,394 & 1,394 & 82 & 82 \\
\hline R-squared & 0.370 & 0.373 & 0.590 & 0.646 \\
\hline Number of localities & 697 & 697 & 41 & 41 \\
\hline Localities fixed-effects & YES & YES & YES & YES \\
\hline Control variables & YES & YES & YES & YES \\
\hline
\end{tabular}

Notes: Robust standard errors clustered within localities in parentheses. ${ }^{* * *} \mathrm{p}<0.01,{ }^{* *} \mathrm{p}<0.05,{ }^{*} \mathrm{p}<0.1$. Fixed-effects estimations.

All control variables of the baseline estimation (Table 4) are included. Columns (1) and (2) present the same fixed-effects estimations as columns (2) and (4) of Table 4, introducing the stock of internal return migrants as a supplementary control variable. Columns (3) and (4) estimate the impact of the share of returnees observed in the most migratory-intensive neighbouring locality on the sub-sample of localities with no return migration from non-African countries.

PARTICIPATION is participation rate, referring to the 1998/1999 and 2009 local elections. RETURNEES is the stock of return migrants aged over 18 over the total population of the locality aged over 18. RETURNEES - AFRICA (respectively ROW) is the stock of return migrants from African (respectively non-African) countries aged over 18 over the total population of the locality aged over 18. INTERNAL RETURNEES is the stock of return migrants from different Malian cercles aged over 18 over the total population of the locality aged over 18. RETURNEES - AFRICA: NEIGHBOUR (respectively ROW: NEIGHBOUR) is the share of return migrants from African (respectively non-African) countries in the neighbouring locality that counts the higher share of returnees from Africa (respectively, from the rest of the world). When we introduce the share of returnees of the neighbors in Columns (3) and (4), we also control for participation rate in those neighboring localities, namely PARTICIPATION RATE: NEIGHBOUR - AFRICA (respectively ROW). These are the participation rates of the neighbours with the highest share of returnees from African (respectively from non-African) countries. 
Table 7. Is there a diffusion effect?

\begin{tabular}{c|c}
\hline & Gain B - Gain A \\
\hline Average & 0.00099 \\
\hline Localities of the sample where Gain B > Gain A, 1998 & 685 \\
Localities of the sample where Gain B > Gain A, 2009 & $(98.28 \%)$ \\
Localities of the sample where Gain B > Gain A, total & 694 \\
& $(99.57 \%)$ \\
\hline
\end{tabular}

Notes: Comparison of the simulated gain associated with the assumption that all the returnees voted and the predicted gain associated with the presence of returnees.

Gain A is the simulated gain, in terms of participation, of having all the returnees voting. Its average is 0.0019 .

Gain B is the gain, in terms of participation, associated with the presence of returnees as predicted by the econometric model. Its average is 0.0029 .

Numbers in brackets are the percentages of localities of the sample for which Gain B is greater than Gain A. 
Table 8. Returnees and education of the non-migrants - Fixed effect estimations.

\begin{tabular}{|c|c|c|c|c|c|c|c|c|}
\hline \multirow[t]{2}{*}{ Dependent : PARTICIPATION } & (1) & (2) & (3) & (4) & $(5)$ & (6) & (7) & $(8)$ \\
\hline & \multicolumn{2}{|c|}{ LITERACY } & \multicolumn{2}{|c|}{ PRIMARY } & \multicolumn{2}{|c|}{ SECONDARY } & \multicolumn{2}{|c|}{ TERTIARY } \\
\hline \multirow[t]{2}{*}{ RETURNEES } & $0.450 * *$ & & 0.320 & & 0.0663 & & 0.0611 & \\
\hline & $(0.226)$ & & $(0.196)$ & & $(0.142)$ & & $(0.143)$ & \\
\hline \multirow[t]{2}{*}{ RETURNEES x EDUCATION } & $-3.322 * *$ & & $-6.333 * *$ & & -1.871 & & 0.0535 & \\
\hline & $(1.574)$ & & $(2.752)$ & & $(2.756)$ & & $(12.67)$ & \\
\hline \multirow[t]{2}{*}{ RETURNEES - AFRICA } & & $0.402 *$ & & 0.252 & & 0.0185 & & 0.0254 \\
\hline & & $(0.228)$ & & $(0.193)$ & & $(0.141)$ & & $(0.145)$ \\
\hline \multirow[t]{2}{*}{ RETURNEES - AFRICA x EDUCATION } & & $-3.202 *$ & & $-6.044 * *$ & & -1.035 & & 1.649 \\
\hline & & $(1.633)$ & & $(2.813)$ & & $(3.100)$ & & $(13.18)$ \\
\hline \multirow[t]{2}{*}{ RETURNEES - REST OF THE WORLD } & & $1.889^{*}$ & & $2.360 * * *$ & & $1.392 * *$ & & $0.817^{*}$ \\
\hline & & $(1.130)$ & & $(0.802)$ & & $(0.680)$ & & $(0.427)$ \\
\hline \multirow[t]{2}{*}{ RETURNEES - ROW x EDUCATION } & & -7.344 & & $-20.37 * *$ & & -12.90 & & -1.751 \\
\hline & & $(6.868)$ & & $(9.424)$ & & $(12.68)$ & & $(63.80)$ \\
\hline Observations & 1,394 & 1,394 & 1,394 & 1,394 & 1,394 & 1,394 & 1,394 & 1,394 \\
\hline $\mathrm{R}$-squared & 0.373 & 0.376 & 0.375 & 0.379 & 0.378 & 0.381 & 0.377 & 0.379 \\
\hline Number of localities & 697 & 697 & 697 & 697 & 697 & 697 & 697 & 697 \\
\hline Joint significance of RETURNEES and RET. $x$ EDUC. & 0.0962 & & 0.0715 & & 0.7710 & & 0.8996 & \\
\hline Joint significance of RETURNEES - AF and RET. - AF x EDUC. & & 0.1393 & & 0.0961 & & 0.9455 & & 0.9640 \\
\hline Joint significance of RETURNEES - ROW and RET. - ROW x EDU & $\overline{\mathrm{UC}}$. & 0.0910 & & 0.0078 & & 0.0587 & & 0.1312 \\
\hline Localities fixed effects & YES & YES & YES & YES & YES & YES & YES & YES \\
\hline Control variables & YES & YES & YES & YES & YES & YES & YES & YES \\
\hline
\end{tabular}

Notes: Robust standard errors clustered within locality in parentheses. ${ }^{* * *} \mathrm{p}<0.01, * * \mathrm{p}<0.05, * \mathrm{p}<0.1$. Fixed-effects estimations.

All control variables of the baseline estimation (Table 4) are included. We also control for the EDUCATION variable introduced in interaction with RETURNEES, RETRUNEES - AFRICA and RETURNEES - REST OF THE WORLD.PARTICIPATION is participation rate, referring to the 1998/1999 and 2009 local elections. RETURNEES is the stock of return migrants aged over 18 over the total population of the locality aged over 18. RETURNEES - AFRICA (respectively REST OF THE WORLD) is the stock of return migrants from African (respectively nonAfrican) countries aged over 18 over the total population of the locality aged over 18. LITERACY is the share of the non-migrant population aged over 18 that is literate. PRIMARY is the share of the non-migrant population aged over 18 that completed primary education. SECONDARY is the share of the non-migrant population aged over 18 that completed secondary education. TERTIARY is the share of the non-migrant population aged over 18 completed tertiary education. 
Table 9. Returnees and the nature of the votes.

\begin{tabular}{lcccccc}
\hline & $(1)$ & $(2)$ & $(3)$ & $(4)$ & $(5)$ & $(6)$ \\
& MAJ & FRAG & GAP & MAJ & FRAG & GAP \\
\hline RETURNEES & $-0.401^{*}$ & $0.564^{* *}$ & $-0.779^{* *}$ & & & \\
& $(0.210)$ & $(0.254)$ & $(0.342)$ & & & \\
RETURNEES - AFRICA & & & & -0.289 & 0.424 & -0.503 \\
& & & & $(0.223)$ & $(0.264)$ & $(0.354)$ \\
RETURNEES - REST OF THE WORLD & & & $-1.717^{* * *}$ & $2.192^{* *}$ & $-4.079^{* * *}$ \\
& & & & $(0.501)$ & $(1.011)$ & $(1.051)$ \\
\hline Observations & 1,394 & 1,394 & 1,394 & 1,394 & 1,394 & 1,394 \\
R-squared & 0.540 & 0.557 & 0.328 & 0.543 & 0.559 & 0.335 \\
Number of localities & 697 & 697 & 697 & 697 & 697 & 697 \\
Localities fixed-effects & YES & YES & YES & YES & YES & YES \\
Control variables & YES & YES & YES & YES & YES & YES \\
\hline
\end{tabular}

Notes: Robust standard errors clustered within localities in parentheses. ${ }^{* * *} \mathrm{p}<0.01,{ }^{* *} \mathrm{p}<0.05,{ }^{*} \mathrm{p}<0.1$. Fixed-effects estimations.

All control variables of the baseline estimation (Table 4) are included. The complete results are shown in Annex D.

RETURNEES is the stock of return migrants aged over 18 over the total population of the locality aged over 18. RETURNEES - AFRICA

(respectively REST OF THE WORLD) is the stock of return migrants from African (respectively non-African) countries aged over 18 over the total population of the locality aged over 18 .

The dependent variable is MAJ, the share of the votes obtained by the elected majority (columns (1) and (4)); FRAG, the index of

political fragmentation (columns (2) and (5)); and, GAP, the difference between the percentages of votes for the first and second lists (columns (3) and (6)) in the local elections of 1998/1999 and 2009. 
Figure 1. Participation rate and domination of ADEMA by communes, 1998-1999 and 2009.

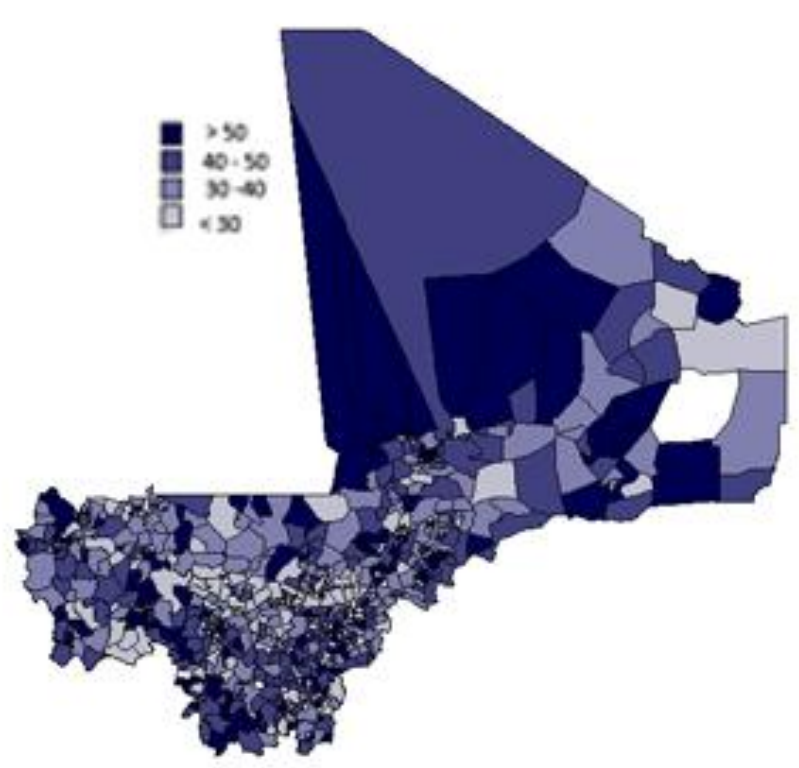

Participation rate by communes - 1999

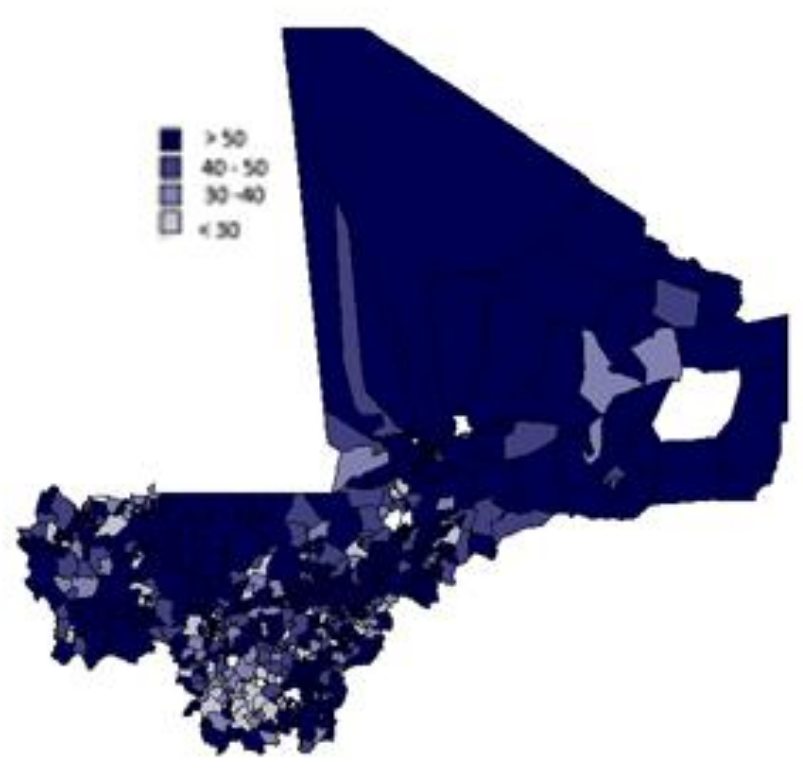

Share of votes for ADEMA by communes - 1999

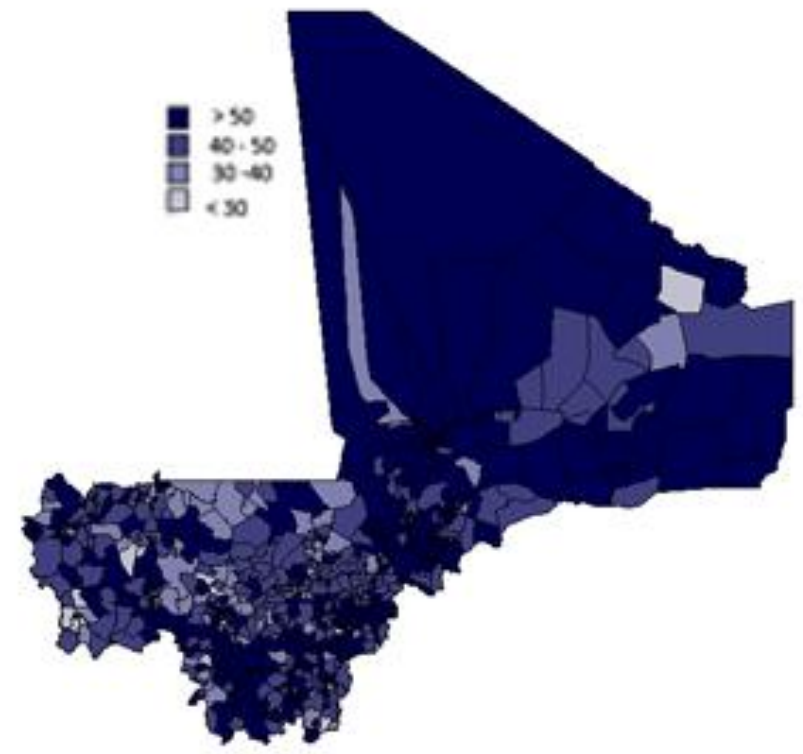

Participation rate by communes - 2009

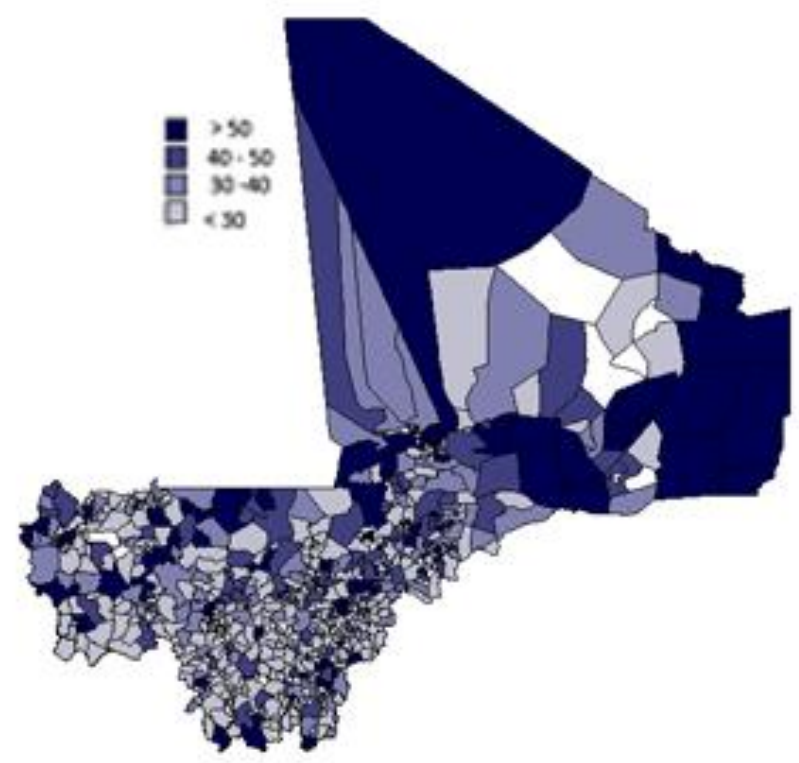

Share of votes for ADEMA by communes - 2009 
Figure 2. Share of returnees by commune and by previous host region, 1998 and 2009.
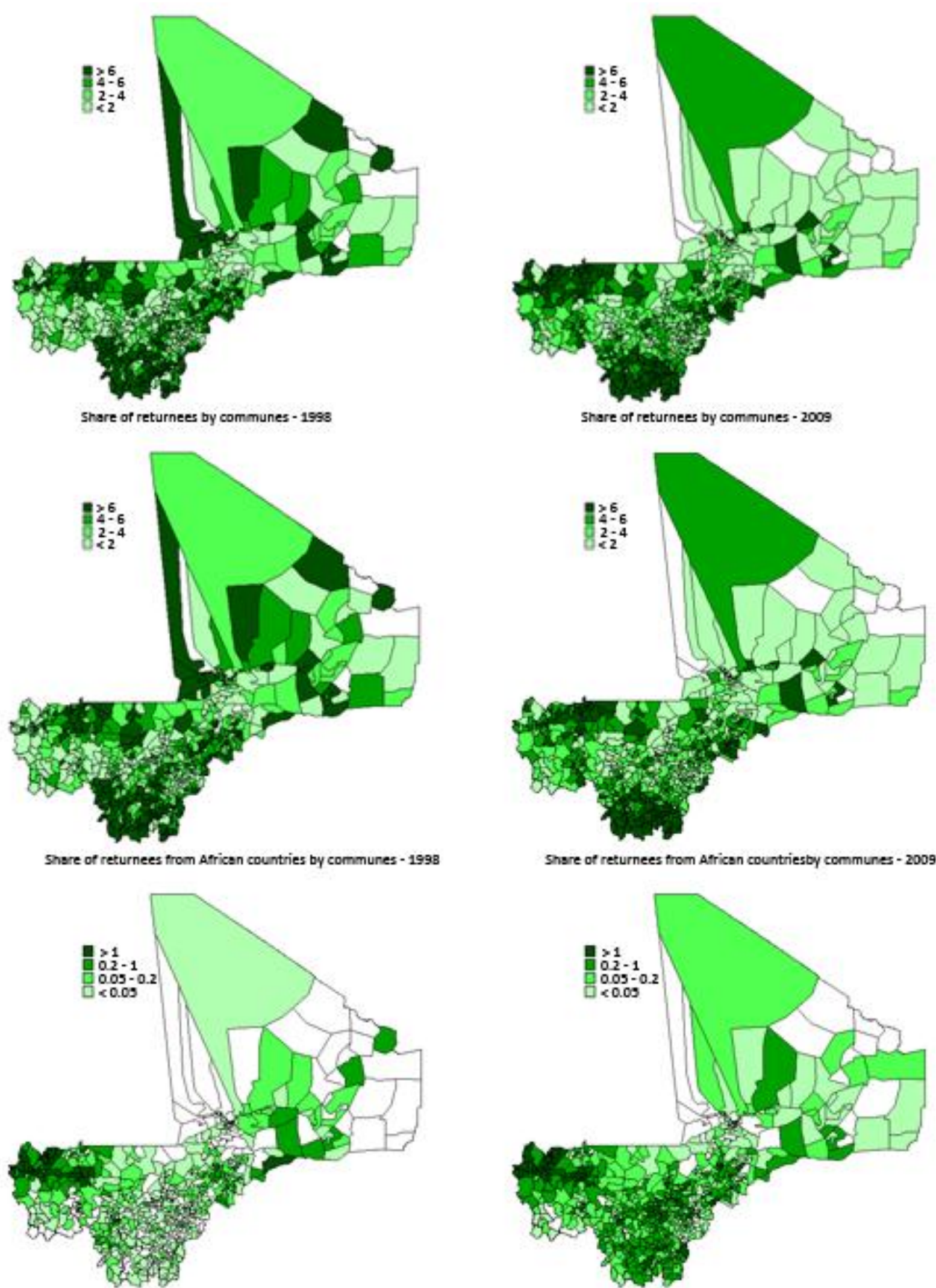

Share of returnees from African countriesby communes - 2009

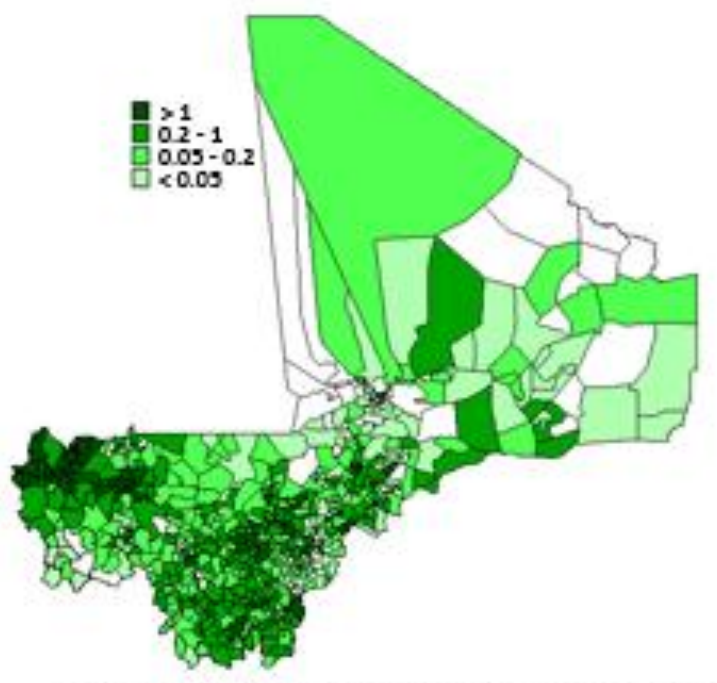

Share of returnees from non-African countries by communes - 1998

Share of returnees from non-African countries by communes - 2009 
Figure 3. Marginal effect of RETURNEES - REST OF THE WORLD on PARTICIPATION, depending on the share of non-migrants who completed primary education.

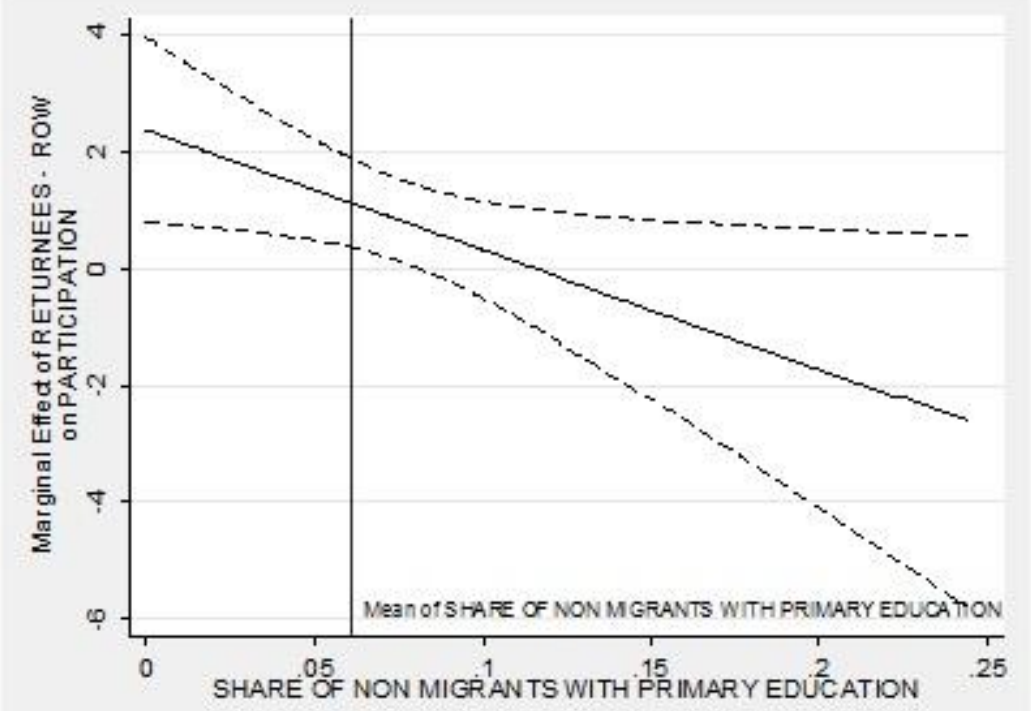

Dashed lines gives 95\% confidence interval. 
Annex A. Polity IV index in Mali, Africa and West Africa (1960-2010).

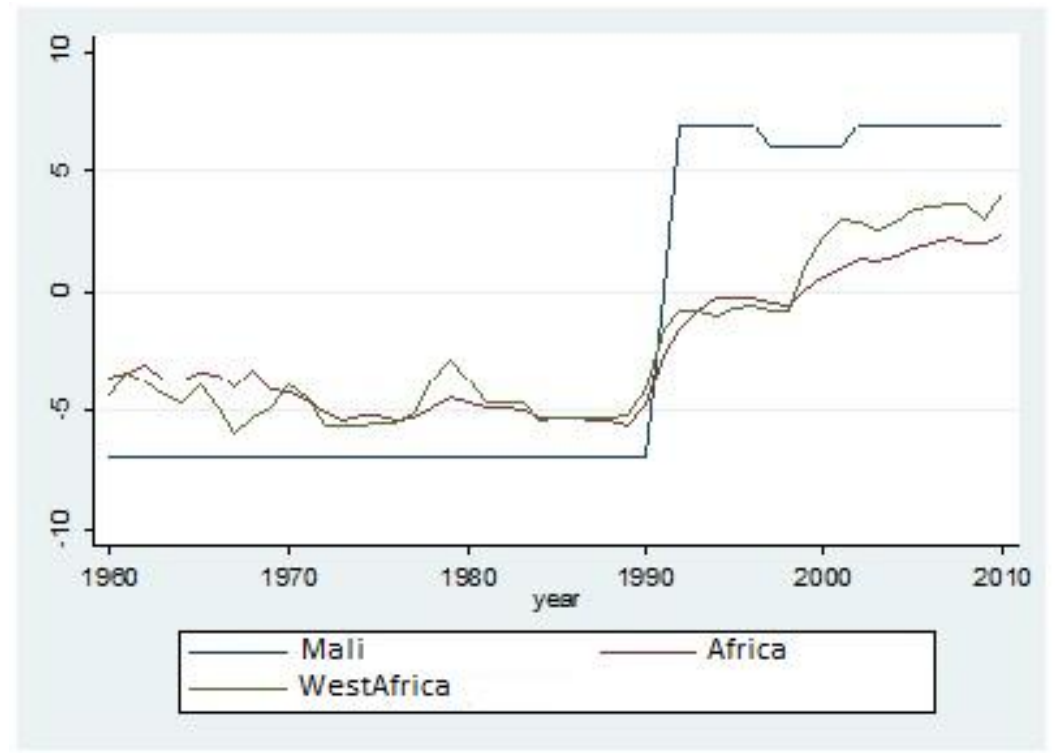

Note: Polity IV (Marshall and Jaggers, 2002) is an index of democracy provided by the Integrated Network for Societal Conflict Research (INSCR) of the Center for Systemic Peace. It assigns to each country an annual score in the autocracydemocracy spectrum, ranging from -10 (autocracy) to 10 (full democracy). 
Annex B. Descriptive statistics for the Malian returnees and total population, 1998 - 2009.

\begin{tabular}{|c|c|c|c|c|c|c|c|c|}
\hline & \multicolumn{2}{|c|}{ Total } & \multicolumn{2}{|c|}{ Mean Age } & \multicolumn{2}{|c|}{$\%$ Women } & \multicolumn{2}{|c|}{$\%$ Literate } \\
\hline & 1998 & 2009 & 1998 & 2009 & 1998 & 2009 & 1998 & 2009 \\
\hline Returnees & 287,497 & 436,385 & 33 & 33.5 & $33 \%$ & $37.5 \%$ & $22 \%$ & $25.5 \%$ \\
\hline Returnees - Africa & 274,855 & $376,595^{\mathrm{a}}$ & 33 & 34.5 & $33.5 \%$ & $37 \%$ & $21.5 \%$ & $26 \%$ \\
\hline Returnees - Rest of the World & 12,642 & $55,084^{\mathrm{a}}$ & 40.5 & 29.5 & $23 \%$ & $40 \%$ & $38 \%$ & $24 \%$ \\
\hline Returnees $\geq 18$ & 216,273 & 329,946 & 41 & 41 & $28.5 \%$ & $34 \%$ & $24.5 \%$ & $27.5 \%$ \\
\hline Returnees - Africa $\geq 18$ & 205,766 & $294,939^{\mathrm{a}}$ & 40.5 & 41 & $29 \%$ & $33.5 \%$ & $23.5 \%$ & $27 \%$ \\
\hline Returnees - Rest of the World $\geq 18$ & 10,507 & $32,952^{\mathrm{a}}$ & 47 & 43 & $18 \%$ & $34 \%$ & $40.5 \%$ & $32.5 \%$ \\
\hline Malian Population & $9,735,499$ & $14,528,973$ & 22 & 21 & $50.5 \%$ & $50.5 \%$ & $12 \%$ & $16.5 \%$ \\
\hline Malian Population $\geq 18$ & $4,605,116$ & $6,484,807$ & 38 & 36.5 & $52 \%$ & $51.5 \%$ & $17.5 \%$ & $24 \%$ \\
\hline
\end{tabular}

Source: Authors' calculations from RGPH, 1998 and 2009

${ }^{a}$ In 2009, the sum of returnees from Africa and returnees from the rest of the world does not equal the total stock of returnees because the destination of the migration is unknown for

4,706 returnees $(2,055$ of them are aged over 18$)$. 
Annex C. Instrumentation strategy: full results.

\begin{tabular}{|c|c|c|}
\hline Dependent : PARTICIPATION & (1) & (2) \\
\hline \multirow[t]{2}{*}{ RETURNEES } & -0.388 & \\
\hline & $(0.669)$ & \\
\hline \multirow[t]{2}{*}{ RETURNEES - AFRICA } & & -1.157 \\
\hline & & $(0.780)$ \\
\hline \multirow[t]{2}{*}{ RETURNEES - REST OF THE WORLD } & & $7.491^{*}$ \\
\hline & & $(4.164)$ \\
\hline \multirow[t]{2}{*}{ LISTS } & -0.00130 & -0.00163 \\
\hline & $(0.00160)$ & $(0.00184)$ \\
\hline \multirow[t]{2}{*}{ POPULATION (LOG) } & -0.0148 & -0.0137 \\
\hline & $(0.0295)$ & $(0.0316)$ \\
\hline \multirow[t]{2}{*}{ LITERACY } & 0.102 & 0.138 \\
\hline & $(0.161)$ & $(0.186)$ \\
\hline \multirow[t]{2}{*}{ WEALTH } & $-0.0311^{*}$ & $-0.0438 * *$ \\
\hline & $(0.0173)$ & $(0.0189)$ \\
\hline \multirow[t]{2}{*}{ RAIN SHOCKS } & -0.000609 & -0.000545 \\
\hline & $(0.000484)$ & $(0.000546)$ \\
\hline \multirow[t]{2}{*}{ PEUL/FOULFOULBE } & 0.227 & 0.198 \\
\hline & $(0.182)$ & $(0.206)$ \\
\hline \multirow[t]{2}{*}{ SONRAI/DJEMA } & $0.872 * *$ & $0.840^{*}$ \\
\hline & $(0.428)$ & $(0.467)$ \\
\hline \multirow[t]{2}{*}{ MARAKA/SONINKE } & 0.354 & 0.224 \\
\hline & $(0.230)$ & $(0.257)$ \\
\hline \multirow[t]{2}{*}{ DOGON } & 0.124 & 0.218 \\
\hline & $(0.314)$ & $(0.438)$ \\
\hline \multirow[t]{2}{*}{ MAURE/ARABE } & 0.0566 & -0.182 \\
\hline & $(0.417)$ & $(0.487)$ \\
\hline \multirow[t]{2}{*}{ TAMACHEQ } & 0.413 & 0.310 \\
\hline & $(0.370)$ & $(0.416)$ \\
\hline \multirow[t]{2}{*}{ MINIANKA } & 0.149 & 0.186 \\
\hline & $(0.128)$ & $(0.151)$ \\
\hline \multirow[t]{2}{*}{ OTHER } & 0.173 & 0.0128 \\
\hline & $(0.187)$ & $(0.211)$ \\
\hline \multirow[t]{2}{*}{ YEAR 2009} & $0.113 * * *$ & $0.0929 * * *$ \\
\hline & $(0.0159)$ & $(0.0201)$ \\
\hline \multicolumn{3}{|l|}{ Instrumentation tests } \\
\hline F-test RETURNEES & 12.10 & \\
\hline \multicolumn{2}{|l|}{ F-test RETURNEES - AFRICA } & 8.17 \\
\hline \multicolumn{2}{|l|}{ F-test RETURNEES - REST OF THE WORLD } & 3.77 \\
\hline Underidentification test & 0.0000 & 0.0066 \\
\hline Overidentification test & 0.7323 & 0.7862 \\
\hline
\end{tabular}


Annex C. Instrumentation strategy: full results (continued).

\begin{tabular}{lc}
\hline First stage for RETURNEES & $(1)$ \\
\hline Distance Migratory Route & $-0.000106^{* * *}$ \\
& $(2.16 \mathrm{e}-05)$ \\
Distance Bamako & $0.0000822^{* * *}$ \\
& $(1.87 \mathrm{e}-05)$ \\
\hline
\end{tabular}

First stage for RETURNEES - AFRICA

Distance Migratory Route

$-0.0000907 * * *$

(3.08e-05)

Distance Bamako

$0.0000613^{* * *}$

$(2.07 \mathrm{e}-05)$

Distance Kayes

0.00000976

$(1.55 \mathrm{e}-05)$

Distance Côte d'Ivoire

$0.0000637 * *$

(3.21e-05)

Distance France

$0.0000466 * *$

$(2.30 \mathrm{e}-05)$

First stage for RETURNEES - REST OF THE WORLD

Distance Migratory Route

$-0.0000234 * * *$

(6.21e-06)

Distance Bamako

0.00000408

$(3.77 \mathrm{e}-06)$

Distance Kayes

$0.0000105^{* * *}$

Distance Côte d'Ivoire

0.00000661

$(5.90 \mathrm{e}-06)$

Distance France

0.00000315

(3.32e-06)

Observations

1,394

R-squared

1,394

0.137

Number of localities

0.359

697

Localities fixed effects

YES

Notes: ${ }^{* * *} \mathrm{p}<0.01,{ }^{* *} \mathrm{p}<0.05,{ }^{*} \mathrm{p}<0.1$. Robust standard errors clustered within localities in parentheses. FixedEffects instrumental estimations.

PARTICIPATION is participation rate, referring to the 1998/1999 and 2009 local elections. RETURNEES is the stock of return migrants aged over 18 over the total population of the locality aged over 18. RETURNEES -

AFRICA (respectively REST OF THE WORLD) is the stock of return migrants from African (respectively nonAfrican) countries aged over 18 over the total population of the locality aged over 18. LISTS is the number of lists in the current election; POPULATION is the logarithm of the locality's population aged 18 and more LITERACY is the share of the population of the locality aged over 18 that is literate ; WEALTH is a composite index of the wealth per capita of the locality; RAIN SHOCKS is the standard deviation of the rain shocks over the ten years preceding the ballot; and PEUL/FOULFOULBE - OTHER are the share of the population aged over 18 of each ethnic group in the locality (based on spoken language).

The distances to Bamako and to the traditional migratory route are used as instruments for RETURNEES, and the distances to Bamako, to the traditional migratory route, to Kayes, to Côte d'Ivoire and to France are used as instruments for RETURNEES - AFRICA and RETURNEES - REST OF THE WORLD. Distances are interacted with a period indicator. 
Annex D. Returnees and the nature of the votes - full results.

\begin{tabular}{lcccccc}
\hline & $(1)$ & $(2)$ & $(3)$ & $(4)$ & $(5)$ & $(6)$ \\
& MAJ & FRAG & GAP & MAJ & FRAG & GAP \\
\hline RETURNEES & $-0.401^{*}$ & $0.564^{* *}$ & $-0.779^{* *}$ & & & \\
RETURNEES - AFRICA & $(0.210)$ & $(0.254)$ & $(0.342)$ & & & \\
& & & & -0.289 & 0.424 & -0.503 \\
RETURNEES - REST OF THE WORLD & & & $(0.223)$ & $(0.264)$ & $(0.354)$ \\
& & & & $-1.717^{* * *}$ & $2.192^{* *}$ & $-4.079^{* * *}$ \\
\hline LISTS & $-0.0179^{* * *}$ & $0.0222^{* * *}$ & $-0.0118^{* * *}$ & $-0.0179^{* * *}$ & $0.0221^{* * *}$ & $-0.0116^{* * *}$ \\
& $(0.00272)$ & $(0.00370)$ & $(0.00389)$ & $(0.00272)$ & $(0.00370)$ & $(0.00390)$ \\
POPULATION (LOG) & $0.117^{* * *}$ & $-0.136^{* * *}$ & $0.180^{* * *}$ & $0.117 * * *$ & $-0.135^{* * *}$ & $0.179^{* * *}$ \\
& $(0.0366)$ & $(0.0432)$ & $(0.0599)$ & $(0.0366)$ & $(0.0432)$ & $(0.0598)$ \\
LITERACY & -0.0530 & -0.145 & 0.00206 & -0.0592 & -0.137 & -0.0133 \\
WEALTH & $(0.135)$ & $(0.162)$ & $(0.219)$ & $(0.135)$ & $(0.161)$ & $(0.217)$ \\
RAIN SHOCKS & -0.00982 & 0.0204 & -0.0213 & -0.00771 & 0.0178 & -0.0159 \\
PEUL/FOULFOULBE & $(0.0181)$ & $(0.0223)$ & $(0.0294)$ & $(0.0181)$ & $(0.0225)$ & $(0.0293)$ \\
& $0.00180^{* * *}$ & $-0.00240^{* * *}$ & $0.00217^{* *}$ & $0.00179^{* * *}$ & $-0.00239^{* * *}$ & $0.00214^{* *}$ \\
SONRAI/DJEMA & $(0.000648)$ & $(0.000772)$ & $(0.00104)$ & $(0.000647)$ & $(0.000772)$ & $(0.00104)$ \\
& $-0.660^{* * *}$ & $0.981^{* * *}$ & $-0.790^{*}$ & $-0.655^{* * *}$ & $0.975^{* * *}$ & $-0.778^{*}$ \\
MARAKA/SONINKE & $(0.253)$ & $(0.320)$ & $(0.411)$ & $(0.251)$ & $(0.317)$ & $(0.404)$ \\
DOGON & $-0.637^{*}$ & 0.387 & $-1.069^{*}$ & $-0.630^{*}$ & 0.378 & $-1.050^{*}$ \\
& $(0.371)$ & $(0.491)$ & $(0.625)$ & $(0.368)$ & $(0.487)$ & $(0.618)$ \\
& -0.224 & 0.443 & -0.138 & -0.201 & 0.415 & -0.0829 \\
& $(0.324)$ & $(0.379)$ & $(0.525)$ & $(0.325)$ & $(0.379)$ & $(0.522)$ \\
& $-0.697^{* *}$ & 0.644 & $-1.245^{* *}$ & $-0.711^{* *}$ & 0.662 & $-1.283^{* *}$ \\
& $(0.330)$ & $(0.474)$ & $(0.532)$ & $(0.323)$ & $(0.476)$ & $(0.511)$ \\
\hline
\end{tabular}


Annex D. Returnees and the nature of the votes - full results (continued).

\begin{tabular}{lcccccc}
\hline MAURE/ARABE & -0.588 & $1.082^{* *}$ & $-1.398^{*}$ & -0.548 & $1.033^{*}$ & -1.300 \\
TAMACHEQ & $(0.451)$ & $(0.535)$ & $(0.839)$ & $(0.447)$ & $(0.529)$ & $(0.826)$ \\
& -0.422 & 0.473 & $-0.790^{*}$ & -0.403 & 0.450 & -0.744 \\
MINIANKA & $(0.280)$ & $(0.344)$ & $(0.463)$ & $(0.279)$ & $(0.340)$ & $(0.458)$ \\
& $-0.620^{* * *}$ & 0.00502 & $-1.062^{* * *}$ & $-0.627^{* * *}$ & 0.0140 & $-1.081^{* * *}$ \\
OTHER & $(0.199)$ & $(0.262)$ & $(0.351)$ & $(0.197)$ & $(0.266)$ & $(0.348)$ \\
& 0.00456 & -0.132 & 0.0232 & 0.0305 & -0.164 & 0.0870 \\
YEAR 2009 & $(0.193)$ & $(0.229)$ & $(0.311)$ & $(0.191)$ & $(0.225)$ & $(0.305)$ \\
& $-0.153^{* * *}$ & $0.192^{* * *}$ & $-0.201^{* * *}$ & $-0.150^{* * *}$ & $0.188^{* * *}$ & $-0.193^{* * *}$ \\
\hline Constant & $(0.0206)$ & $(0.0248)$ & $(0.0319)$ & $(0.0207)$ & $(0.0248)$ & $(0.0320)$ \\
& 0.0209 & $1.239^{* * *}$ & -0.615 & 0.00262 & $1.262^{* * *}$ & -0.661 \\
& $(0.363)$ & $(0.419)$ & $(0.587)$ & $(0.363)$ & $(0.418)$ & $(0.584)$ \\
\hline Observations & 1,394 & 1,394 & 1,394 & 1,394 & 1,394 & 1,394 \\
R-squared & 0.540 & 0.557 & 0.328 & 0.543 & 0.559 & 0.335 \\
Number of localities & 697 & 697 & 697 & 697 & 697 & 697 \\
Localities fixed-effects & YES & YES & YES & YES & YES & YES \\
\hline
\end{tabular}

Notes: Robust standard errors clustered within localities in parentheses. ${ }^{* * *} \mathrm{p}<0.01, * * \mathrm{p}<0.05,{ }^{*} \mathrm{p}<0.1$. Fixed-effects estimations. PARTICIPATION is participation rate, referring to the 1999 and 2009 local elections. RETURNEES is the stock of return migrants aged over 18 over the total population of the locality aged over 18. RETURNEES - AFRICA (respectively REST OF THE WORLD) is the stock of return migrants from African (respectively non-African) countries aged over 18 over the total population of the locality aged over 18. LISTS is the number of lists in the current election; POPULATION is the logarithm of the locality's population aged 18 and more LITERACY is the share of the population of the locality aged over 18 that is literate ; WEALTH is a composite index of the wealth per capita of the locality; RAIN SHOCKS is the standard deviation of the rain shocks over the ten years preceding the ballot; and PEUL/FOULFOULBE - OTHER are the share of the population aged over 18 of each ethnic group in the locality (based on spoken language). The dependent variable is MAJ, the share of the votes obtained by the elected majority (columns (1) and (4)); FRAG, the index of political fragmentation (columns (2) and (5)); and, GAP, the difference between the percentages of votes for the first and second lists (columns (3) and (6)) in the local elections of 1998/1999 and 2009. 